\title{
ENHANCING THE ALBERTA TAX ADVANTAGE WITH A HARMONIZED SALES TAX
}

\author{
Philip Bazel and Jack M. Mintz \\ The School of Public Policy, University of Calgary
}

\section{SUMMARY}

Alberta enjoys a reputation as a fiercely competitive jurisdiction when it comes to tax rates. But the reality is that the province can do better with a tax mix that has greater emphasis on consumption, rather than income tax levies.

While Alberta has a personal tax advantage compared to other Canadian jurisdictions - but not the United States - it relies most heavily on income taxes and non-resource revenues that impinges on investment and saving. Taxes on new investment in Alberta's non-resource sectors are no better than average, compared to other countries in the Organization for Economic Cooperation and Development, or OECD, so it is not exceptionally attractive to many different kinds of investors. And Alberta's corporate income tax rate is not much more competitive than the world average for manufacturing and service companies.

By introducing the Harmonized Sales Tax with a provincial rate of 8 per cent (in addition to the federal 5 per cent rate), Alberta has the ability to make its tax system more competitive. An HST would even allow the province to entirely eliminate income tax for the majority of families. And because the HST would be easily administered using the same collection mechanisms that already exist for the GST, implementing a new Alberta HST could be done relatively smoothly and with minimal additional administration costs. Adopting an Alberta HST is the simplest, most efficient and fairest way to reform the provincial tax system, and will deliver noticeable benefits to Albertans, most visibly in the form of significant income tax relief.

It would enable the province to raise the income-tax exemption from $\$ 17,593$ to $\$ 57,250$, making it possible for couples to earn up to $\$ 114,500$ free of any provincial income taxes. In addition, the province could lower income tax rates for income over that amount from 10 to nine per cent. And with the revenue from the HST, Alberta would have the capacity to lower its general corporate income tax from 10 to 8.43 per cent, reducing taxes on investment. An HST could also bring in an estimated $\$ 800$ million in additional annual revenue from tourists and visitors, and would likely entitle the province to a $\$ 1.3$ billion HST transition payment from the federal government.

If the government can convince Albertans that the sales tax would be revenue neutral, and can promise simultaneous significant tax cuts to personal incomes, as well as corporate tax reductions that will enhance Alberta's competitiveness, then winning public support is possible. The task of persuading the public must fall to bold politicians. But if provincial legislators truly value tax fairness, competitiveness, and the future fiscal stability of the province, they have a duty to convince voters that an HST is the right choice for Alberta.

\footnotetext{
$\dagger$ We wish to thank Duanjie Chen for providing some of the statistics needed in this report. We also thank two anonymous referees for their detailed criticisms that helped us to remarkably improve this paper. We also thank Nancy Cuelenaere and Blair Nixon for helpful comments as well.

Some of the analysis presented in this paper is based on Statistics Canada's Social Policy Simulation Database Model. The assumptions and calculations underlying the simulation were prepared by the authors and the responsibility for the use and interpretation of these data rests entirely with them.
} 


\section{INTRODUCTION}

The tax system is a contract between the government and its citizens. Taxes fund public services desired by the population. Taxes also affect how resources are distributed among Albertans, with some paying more for public services than others. Taxation is a powerful tool in affecting the development of an economy. For Alberta, which has benefited from a rich endowment of resources, taxes have historically been kept low as non-renewable resource revenues have contributed to Alberta's overall budget.

Albertans recognize the importance of their tax advantage in growing the provincial economy. As noted in the Budget of 2013-14, "Albertans continue to benefit from one of the most competitive tax systems in North America." This low level of taxation is viewed as Alberta's tax advantage.

In this research study, we focus on issues related to Alberta's mix of taxes, or its tax structure. Given a certain level of taxes needed to fund the provincial government's activities, Alberta has a tax disadvantage with a less than optimally designed tax structure. Simply put, there is too much reliance on volatile, harmful income taxation and not enough reliance on less volatile, less harmful consumption-related levies. While taxes on labour are relatively low, Alberta has little tax advantage when it comes to taxes on new investment. A shift from income taxation to a consumption tax would reduce the tax on investments and risk-taking, enhancing Alberta's tax advantage.

Albertans might think they do not pay consumption-related levies today, but this is not the case. For 2013-14, Alberta expects to collect $\$ 2.45$ billion in fuel, tobacco, insurance, freehold mineral rights, tourism and carbon levies, and $\$ 2.2$ billion in gaming and alcohol revenues. A further $\$ 1.7$ billion is expected to be collected as various user charges (levies associated with the consumption of public services). Alberta also expects to collect $\$ 1.8$ billion in an education property tax (which is related directly to the cost of education). Overall, this amounts to $\$ 8.1$ billion in consumption-related levies. Although less than the $\$ 14.8$ billion collected from personal and corporate income taxes, consumption-related levies are expected to represent 24 per cent of Alberta's own-source revenues in 2013-14. What is missing from the mix of taxes is a general sales tax.

This paper makes the case for the adoption of a Harmonized Sales Tax (HST) in Alberta as a replacement for a portion of personal and corporate income tax revenues. An HST in Alberta could be adopted at little compliance and administrative cost since it could be piggybacked on the federal Goods and Services Tax (GST), which is currently levied at five per cent. Under our proposal, the revenues would be used to reduce personal and corporate income taxes, the former through an increase in the personal income tax exemption and a reduction in the personal income tax rate. With the introduction of a low-income sales-tax credit, Albertans with low or modest incomes will be sheltered from any tax increase. An Alberta HST would increase some taxes on business inputs (financial services, for example), but our proposed reduction in corporate income tax rates will largely offset any increase in business-level taxes. Other options are considered, but this is our primary approach to tax reform. 
The case for an HST in Alberta is presented in the next section, where we discuss the economic gains that would result from a revenue-neutral shift from income to sales taxes. ${ }^{l}$ These gains arise from a reduction in taxes on saving, investment, risk-taking and entrepreneurship, potential diversification of Alberta's economy, as well as new levies on non-residents purchasing goods and services when visiting Alberta. The province would also rely on less volatile own-source revenues. It could also be entitled to a transition payment of $\$ 1.3$ billion from the federal government for harmonizing its sales tax with the federal GST. ${ }^{2}$

This discussion is then followed by our basic proposal of a 13 per cent HST (five points would be the federal rate and eight points would be the provincial rate). The Alberta portion of the HST would raise roughly $\$ 8$ billion of revenue in 2013. The general corporate income tax rate would be reduced from 10 to 8.43 per cent, ${ }^{3}$ the personal income tax exemption would increase from $\$ 17,593$ to $\$ 57,250$, and the personal income tax rate would be reduced from 10 to nine per cent. In addition, we recommend a low-income refundable sales-tax credit that would reduce taxes on lower-income Albertans. This reform would be distributionally neutral, maintaining a progressive personal- and sales-tax structure.

Our basic proposal is just one of many that would need to be discussed in more detail by Albertans. We examine several options:

- Whether the Alberta rate under the HST should be two per cent or five per cent, rather than eight per cent as in our basic proposal.

- Whether the personal income tax rate should be graduated by reducing the tax rate for only some income groups, maintaining or increasing the top rate for high-income earners (thereby moving away from the flat-rate personal income tax with two rates being adopted).

- Whether a tax reform should be revenue-neutral, revenue-increasing or revenue-decreasing in its impact (the adoption of the flat personal income tax in Alberta in 1999 resulted in a reduction of tax revenues), taking into account current deficits and the lack of saving of natural-resource levies, which are instead spent on existing public services and infrastructure.

The final section concludes our discussion with a plea for Albertans to discuss tax reform with evidence-based analysis to improve growth prospects in the future.

1 An earlier argument for a sales tax in Alberta written before Ontario's harmonization with the federal GST was provided by K. McKenzie, Replacing the Alberta Personal Income Tax with a Sales Tax in Alberta: Not Heresy but Good Economic Sense, Canada West Foundation, Calgary, Alberta, 2000. An important difference between our proposal and that of Professor McKenzie is that we would not fully replace the personal income tax with a sales tax since we believe that it is important to continue the use of personal tax revenues to fund public services. We are also explicit in recommending the adoption of the HST in Alberta.

2 Ontario received $\$ 4.6$ billion in federal transition funding over two years. B.C. received $\$ 1.6$ billion, which was later repaid upon repeal of the HST.

3 The provincial dividend tax credit would be adjusted to reflect a lower Alberta corporate income tax rate. 


\section{EXISTING ALBERTA OWN-REVENUE STRUCTURE}

The Alberta government relies on four primary own-source revenue streams: personal and corporate revenues, other tax revenues including excise taxes and user fees, natural-resource revenues, and investment income from funds and Crown corporations. The breakdown of major own-source revenues in accordance with the 2012-13 budget (and estimates for 2013-14) is presented in Table 1.

TABLE 1: CURRENT ALBERTA TAX MIX FOR OWN-SOURCE REVENUES FOR 2012-13 AND 2013-14

\begin{tabular}{|c|c|c|c|c|}
\hline \multirow{2}{*}{$\begin{array}{l}\begin{array}{c}\text { Own-Source Revenue } \\
\text { (millions of dollars) }\end{array} \\
\text { Income Taxes }\end{array}$} & \multicolumn{2}{|c|}{$\begin{array}{c}\text { 2012-13 } \\
\text { As of March } 2013\end{array}$} & \multicolumn{2}{|c|}{$\begin{array}{l}\text { 2013-14 } \\
\text { Estimates }\end{array}$} \\
\hline & $\$ 14,599$ & $44.14 \%$ & $\$ 14,824$ & $44.25 \%$ \\
\hline Personal Income Tax & $\$ 9,627$ & $29.11 \%$ & $\$ 10,001$ & $29.86 \%$ \\
\hline Corporate Income Tax & $\$ 4,972$ & $15.03 \%$ & $\$ 4,823$ & $14.40 \%$ \\
\hline Consumption Taxes - Private Good Related & $\$ 4,557$ & $13.78 \%$ & $\$ 4,652$ & $13.89 \%$ \\
\hline Tobacco Tax & $\$ 910$ & $2.75 \%$ & $\$ 920$ & $2.75 \%$ \\
\hline Fuel Tax & $\$ 890$ & $2.69 \%$ & $\$ 900$ & $2.69 \%$ \\
\hline Tourism Levy & $\$ 80$ & $0.24 \%$ & $\$ 85$ & $0.25 \%$ \\
\hline Insurance Tax & $\$ 312$ & $0.94 \%$ & $\$ 333$ & $0.99 \%$ \\
\hline Freehold Mineral Rights Tax & $\$ 135$ & $0.41 \%$ & $\$ 152$ & $0.45 \%$ \\
\hline Alberta Gaming and Liquor Commission - Gaming & $\$ 1,446$ & $4.37 \%$ & $\$ 1,484$ & $4.43 \%$ \\
\hline Alberta Gaming and Liquor Commission - Liquor & $\$ 714$ & $2.16 \%$ & $\$ 718$ & $2.14 \%$ \\
\hline Climate Change and Emissions Management & $\$ 70$ & $0.21 \%$ & $\$ 60$ & $0.18 \%$ \\
\hline Consumption Taxes - Public Good Related & $\$ 3,265$ & $9.87 \%$ & $\$ 3,407$ & $10.17 \%$ \\
\hline Education Property Tax & $\$ 1,762$ & $5.33 \%$ & $\$ 1,835$ & $5.48 \%$ \\
\hline Motor Vehicle Licences & $\$ 471$ & $1.42 \%$ & $\$ 485$ & $1.45 \%$ \\
\hline Crop, Hail and Livestock Insurance Premiums & $\$ 312$ & $0.94 \%$ & $\$ 313$ & $0.93 \%$ \\
\hline Energy Industry Levies & $\$ 161$ & $0.49 \%$ & $\$ 203$ & $0.61 \%$ \\
\hline Land Titles & $\$ 82$ & $0.25 \%$ & $\$ 85$ & $0.25 \%$ \\
\hline Land and Grazing & $\$ 68$ & $0.21 \%$ & $\$ 69$ & $0.21 \%$ \\
\hline Supplementary Health Benefits Premiums & $\$ 54$ & $0.16 \%$ & $\$ 53$ & $0.16 \%$ \\
\hline 'Other' - Premiums, Fees and Licences & $\$ 355$ & $1.07 \%$ & $\$ 364$ & $1.09 \%$ \\
\hline Non-Renewable Resource Revenue & $\$ 7,171$ & $21.68 \%$ & $\$ 7,250$ & $21.64 \%$ \\
\hline Investment Income & $\$ 2,322$ & $7.02 \%$ & $\$ 2,145$ & $6.40 \%$ \\
\hline Other & $\$ 1,158$ & $3.50 \%$ & $\$ 1,219$ & $3.64 \%$ \\
\hline TOTAL & $\$ 33,072$ & & $\$ 33,497$ & \\
\hline
\end{tabular}

Source: Alberta Budget 2013.

As noted by the table, the Alberta government collects two types of consumption-related revenues. ${ }^{4}$ Some are levies associated with private consumption including excise taxes on tobacco and fuel, gambling and alcohol revenues. Other levies are associated with the consumption of public services: user charges for the provision of public services. The latter is perhaps exemplified by the former health premium and the provincial education property tax, which is explicitly related to program costs.

4 Table 1 is constructed from own-source values in the 2013 Alberta budget. The unique presentation, which makes a distinction between consumption levies for public and private goods, is intended to illustrate the contrast between public and private goods, and identify the revenues that flow from each type of consumption. 
Thus, there are alternative methods by which a jurisdiction such as Alberta could increase consumption-related levies besides imposing a general sales tax. This issue is discussed below under alternative approaches to a general sales tax.

\section{ALBERTA'S FLAT PERSONAL INCOME TAX}

Before we delve into intricacies of a shift in the tax mix for Alberta from income to consumption taxes, it would be helpful to explain as background the current Alberta personal income tax with respect to its incidence - i.e., who pays the tax.

Alberta has a unique personal income tax whereby a single rate of 10 per cent is applied to income in excess of a personal exemption (currently $\$ 17,593$ per individual). Although Alberta's personal tax system is widely referred to as a "flat tax," it really has two rates of taxation: zero for incomes below the exemption and 10 per cent on the excess. This makes the Alberta personal tax a progressive one in the sense that the tax paid as a share of income rises with income.

Alberta has relatively more high-income households than other provinces, as shown in Figure 1 A through to $1 \mathrm{D}$.

As shown in Figure 1A, 10.8 per cent of households have incomes above $\$ 200,000$, and pay 47 per cent of personal income tax revenues. Under the Alberta flat tax, 33.6 per cent of households with incomes below $\$ 60,000$ pay just over three per cent of income taxes. Households with two adults (with or without children) are the most common types of taxpayers (Figure 1B). The elderly currently account for over a fifth of the population but only pay about one-tenth of total personal income taxes. In the future, the elderly population is projected to more than double by 2031..$^{5}$ As the elder part of the population increases in Alberta relative to the working population, there will be some downward pressure on personal tax collections.

As Figure 1C indicates, Alberta has more households with incomes above $\$ 200,000$ than do other provinces. Alberta also has the lowest top federal-provincial marginal tax rate among all provinces (39 per cent) and has a much higher share of households with more than $\$ 500,000$ total income compared to other provinces (Figure 1D).

5 See: Alberta Health Services, Demographic Planning Commission, "Embracing an Aging Population,” 2008, http://www.health.alberta.ca/seniors/aging-population.html. 
FIGURE 1A: DISTRIBUTION OF PERSONAL INCOME TAXES IN ALBERTA BY HOUSEHOLD INCOME (2013)

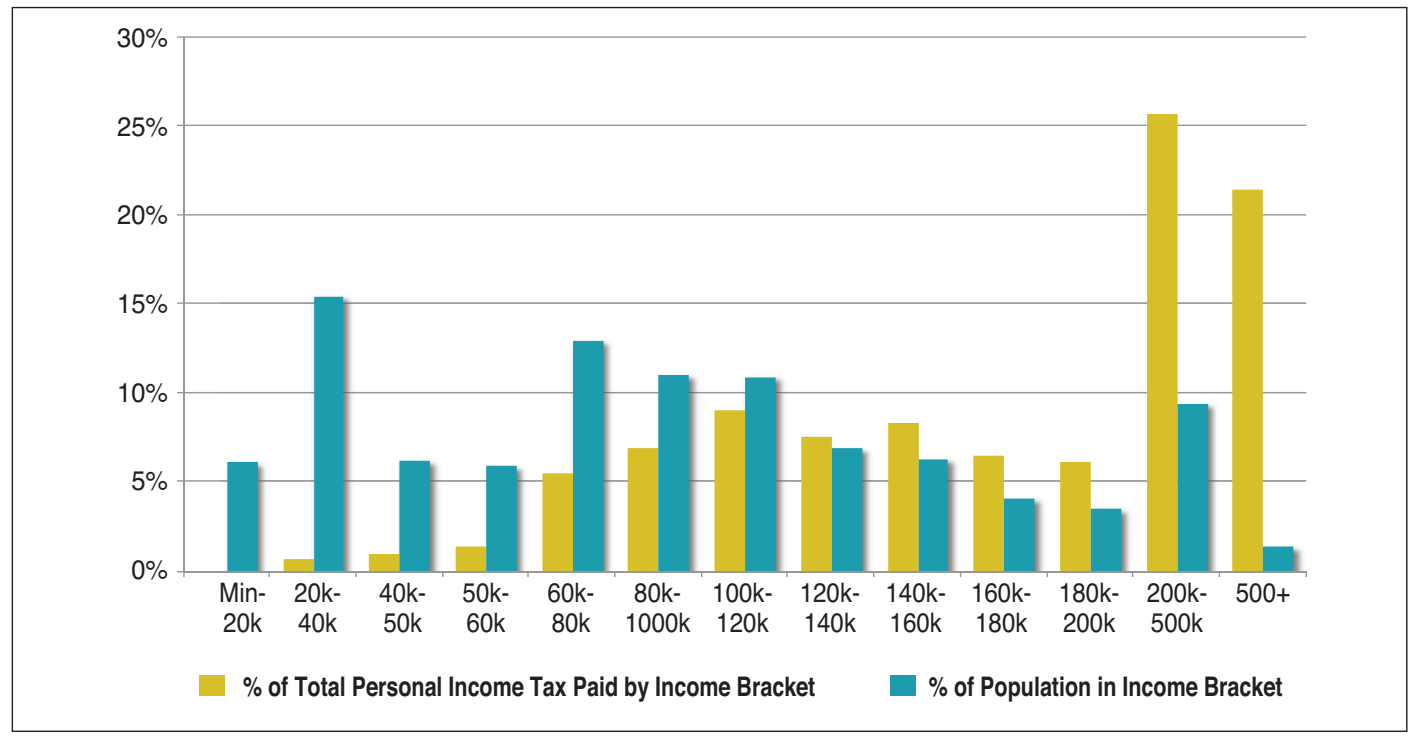

Source: Statistics Canada model SPSD/M.

FIGURE 1B: DISTRIBUTION OF PERSONAL INCOME TAXES IN ALBERTA BY HOUSEHOLD TYPE (2013)

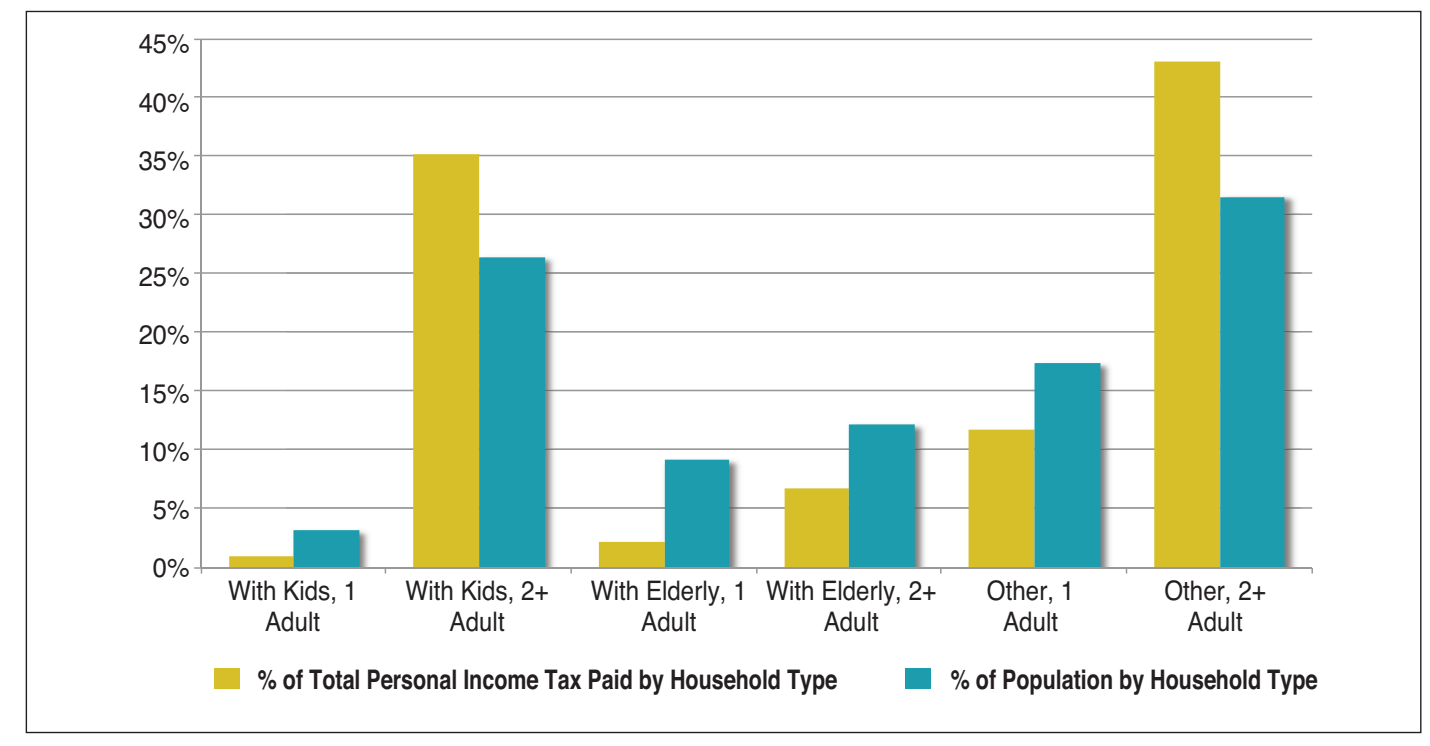

Source: Statistics Canada model SPSD/M. 
FIGURE 1C: HOUSEHOLDS WITH INCOME \$200K +: AS A PERCENTAGE OF TOTAL PROVINCIAL POPULATION AND TOTAL PROVINCIAL PERSONAL INCOME TAX (2013)

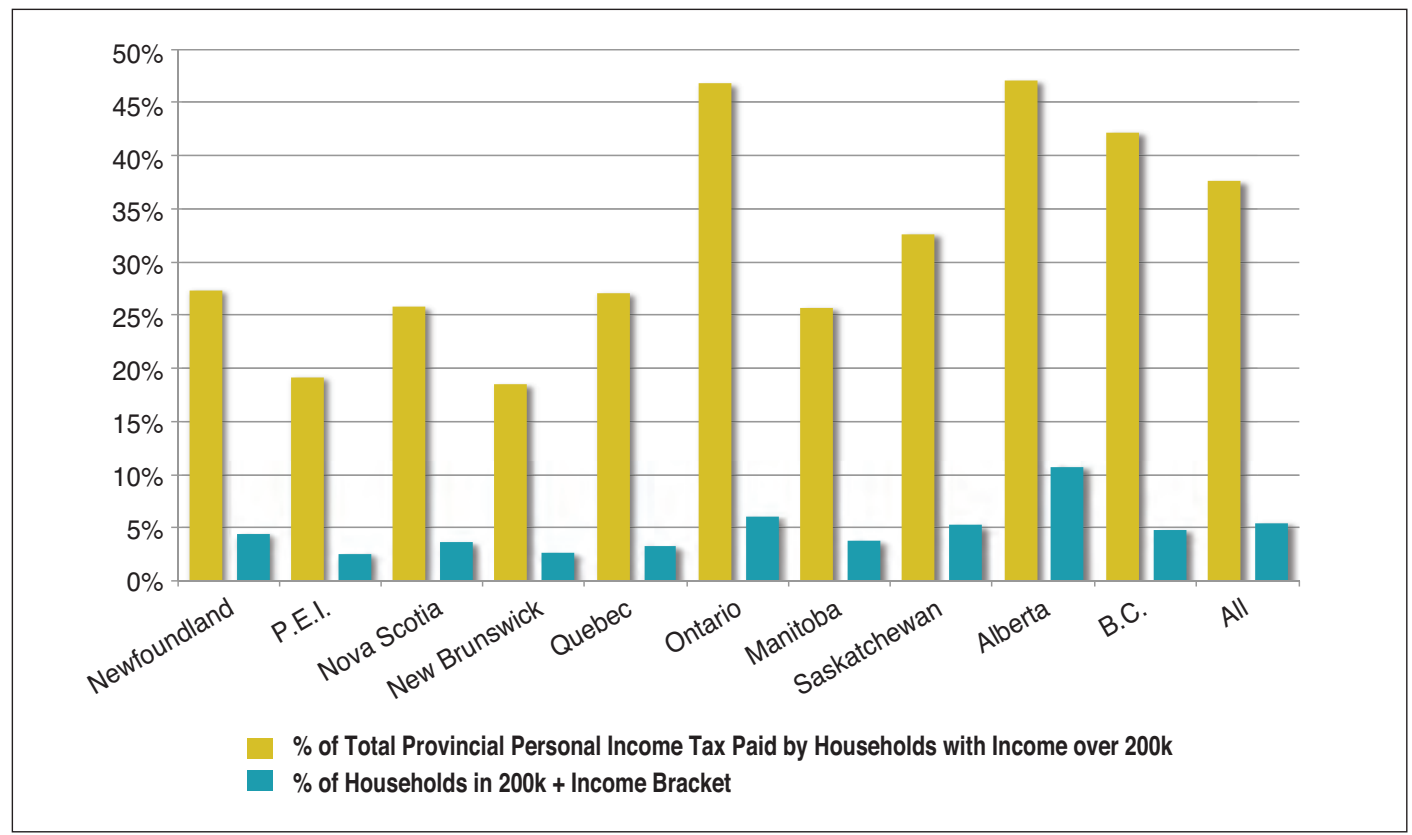

Source: Statistics Canada model SPSD/M.

FIGURE 1D: FEDERAL-PROVINCIAL TOP MARGINAL TAX RATES AND SHARE OF PROVINCIAL TAXABLE INCOME EARNED BY HIGHEST-INCOME HOUSEHOLDS BY PROVINCE (2013)

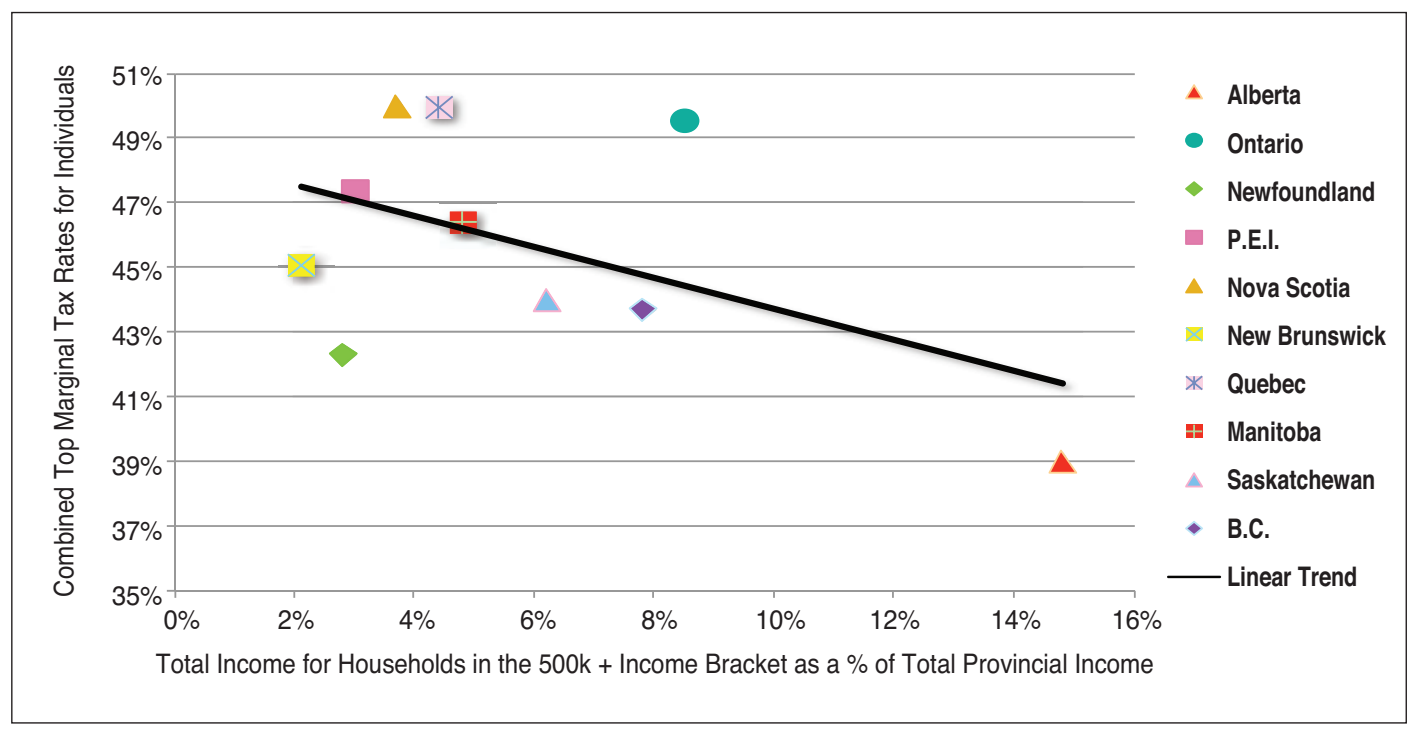




\section{THE CASE FOR AN HST AS A REPLACEMENT FOR A PORTION OF INCOME TAXES IN ALBERTA}

Like other governments, Alberta is faced with the question of how best to raise taxes. The latter question was well articulated by the French minister of finance, Jean Baptist Colbert, three-and-a-half centuries ago: the art of taxation is plucking the largest amount of feathers from the goose with least amount of hissing. No tax is without cost to the economy, so the tax structure, not just the level of taxation, is important public policy.

In this section, we lay out seven reasons for the adoption of an HST as a general sales tax in Alberta with the revenues used to reduce income taxes. These include (a) reducing tax distortions that impose economic costs, (b) encouraging wealth accumulation for future retirement and other needs, (c) reducing taxes on business investment, (d) increasing levies on non-resident consumption in Alberta to help pay for public services provided to tourists, (e) reducing the volatility of non-resource revenues to help manage treasury risk and (f) keeping compliance and administrative costs of the tax system as low as possible. We also evaluate whether a general sales tax such as the HST itself is the best form of the consumption-tax options.

\section{Reducing the Economic Cost of Taxation}

The case for consumption taxation to replace income tax revenues is based on both economic and fairness considerations. The issue centers on the degree to which saving and investment should be taxed.

\section{PROBLEMS WITH AN IDEAL COMPREHENSIVE INCOME TAX ${ }^{6}$}

With comprehensive income taxation, taxpayers would pay tax on income that can be consumed or added to net wealth during the taxation period. Sources of income include payments for the reward of work effort (wages, salaries, benefits and self-employed income), capital income accruing from the holding of assets (interest, dividends, rents and capital gains), and inheritances and gifts.

Comprehensive annual income is argued by some to be the best base for personal taxation since income can be spent on private goods and services, or provide resources for bequests or economic power.

However, comprehensive income taxation has been subject to a variety of criticisms: it imposes significant economic costs on the economy, it is complex, and it can be unfair. The main criticism is related to the higher taxation of investment and saving compared to consumption.

6 This discussion is based on Larry Chapman and Jack Mintz, "Personal Income Taxation," in Tax Policy in Canada, ed. Heather Kerr, Ken McKenzie and Jack Mintz, Canadian Tax Foundation, Toronto, 2012. 
The first proponent of consumption taxation was Sir Nicholas Kaldor, ${ }^{7}$ who argued in favour of the taxation of consumption or expenditure rather than income. David Bradford of Princeton University and the U.K.'s Meade report further developed the arguments as follows. ${ }^{8}$ As illustrated in Table 2 below, a saver with the same lifetime earnings as a consumer pays more tax on a lifetime basis. The reason is that saving is a postponement of consumption into the future. A household that consumes its entire earnings in a year will only pay tax on those earnings once. However, if some of the money is saved, such savings are taxed twice: once when labour income is earned and again when interest income is earned. The interest rate is the price at which people convert current into future consumption - taxing interest and investment income more generally, increases the price of future consumption relative to current consumption.

TABLE 2: COMPREHENSIVE INCOME TAXES: IMPACT ON CONSUMERS AND SAVERS

\begin{tabular}{|l|c|c|c|c|c|c|c|}
\hline Year & $\begin{array}{c}\text { Annual } \\
\text { Earnings } \\
\text { for Both } \\
\text { Individuals }\end{array}$ & $\begin{array}{c}\text { Consumer's } \\
\text { Tax Base }\end{array}$ & $\begin{array}{c}\text { Consumer's } \\
\text { Tax Paid } \\
\text { at 25\% }\end{array}$ & $\begin{array}{c}\text { Consumer's } \\
\text { Tax Time } \\
\text { Value } \\
\text { (discounted) }\end{array}$ & $\begin{array}{c}\text { Saver's } \\
\text { Tax } \\
\text { Base }\end{array}$ & $\begin{array}{c}\text { Tax Paid } \\
\text { by Saver }\end{array}$ & $\begin{array}{c}\text { Savers's } \\
\text { Tax Time } \\
\text { Value } \\
\text { (discounted) }\end{array}$ \\
\hline Year 1 & $\$ 20,000$ & $\$ 20,000$ & $\$ 5,000.00$ & $\$ 5,000.00$ & $\$ 20,000$ & $\$ 5,000.00$ & $\$ 5,000.00$ \\
Year 2 & $\$ 20,000$ & $\$ 20,000$ & $\$ 5,000.00$ & $\$ 4,545.45$ & $\$ 20,500$ & $\$ 5,125.00$ & $\$ 4,659.09$ \\
Year 3 & $\$ 10,000$ & $\$ 10,000$ & $\$ 2,500.00$ & $\$ 2,066.12$ & $\$ 10,550$ & $\$ 2,637.50$ & $\$ 2,179.75$ \\
$\begin{array}{l}\text { Taxes Paid } \\
\text { (Undiscounted) }\end{array}$ & & & $\$ 12,500.00$ & & & & \\
$\begin{array}{l}\text { Time Value } \\
\text { of Taxes Paid }{ }^{(2)}\end{array}$ & & & & $\$ 11,611.57$ & & & \\
\hline
\end{tabular}

Notes:

(1) Assumes that the saver consumes only \$15,000 in Year 1 (saves \$5,000) and earns a 10-per-cent annual return on savings. In the third year, the saver consumes all of his earnings and the principal and interest saved over two years is withdrawn from the bank account and consumed. Interest earned on $\$ 5,000 \times 10$ per cent $=\$ 500$ in the second year. Assuming there is no withdrawal (the interest is reinvested in the account), the interest earned in the second year is $\$ 5,500 \times 10$ per cent $=\$ 550$. The savings account has accumulated $\$ 6,050$ by Year 3 . Interest is taxed each year at 25 per cent.

(2) Time value of taxes paid is the Year 1 equivalent of money. A saver is willing to postpone consumption to the future by giving up consumption in Year 1 in return for interest paid on savings. Thus, $\$ 1$ is of the same value if paid $\$ 1.10$ in Year 2. So, for example, $\$ 1$ of income available in Year 2 is worth $1 / 1.1=90.9$ cents in Year 1 . And \$1 of income in Year 3 is worth $\$ 1 / 1.12=82.6$ cents in Year 1 .

Under a comprehensive income tax, a saver is more heavily taxed than a consumer, which raises a fundamental question of both efficiency (unequal taxation of current and future consumption) and fairness (those who desire more consumption in future years are more heavily taxed).

Other criticisms have been made of comprehensive income taxation, focusing more on its implementation as opposed to a point of principle. These issues have included the difficulties in measuring investment income, taking into account non-traded assets, capital gains and losses, financial derivatives, depreciation of assets and inflation adjustments. No country has satisfactorily implemented an ideal comprehensive income tax with equal burdens on all sources of income. It is just too complex to do so.

7 Nicholas Kaldor, An Expenditure Tax (London: George Allen and Unwin, 1956).

8 See: D. Bradford, Untangling the Income Tax (Cambridge, Mass.: Harvard University Press, 1984); and U.S. Treasury Report, Basic Blueprint for Income Tax Design (Washington, D.C.: U.S. Government Printing Office, 1977). See also Institute for Fiscal Studies, The Structure and Reform of Direct Taxation: Report of a Committee Chaired by Professor J. E. Meade (London: Allen and Unwin, 1978). 


\section{CONSUMPTION TAXATION}

Consumption taxes differ from the income tax by exempting the return on saving in some form. ${ }^{9}$ For example, taxpayers can deduct saving from their income (consumption is income less saving) and be taxed on withdrawal of interest and principal from savings accounts (this approach to consumption taxation is used for RRSPs and pension-saving in Canada under the personal income tax). Another approach is to exempt the return on saving (this applies to consumer durables and tax-free savings accounts in Canada). A third approach is a general sales tax, whereby businesses collect taxes charged on sales to consumers with no tax paid on sales to other businesses. The GST is an example of a sales tax that is levied on goods and services sold to consumers, with little tax on business-to-business sales when the business claims a credit for any taxes paid on purchases from other businesses charging GST on the invoice.

Regardless of the approach to consumption taxation, consumers and savers pay the same tax on a lifetime basis (Table 3). A consumer pays tax on goods and services purchased from consumed earnings in the first period (earnings net of saving). When saving is used in the future to buy goods and services, sales taxes are paid on goods and services bought with earnings and any savings account withdrawals used for consumption.

\section{TABLE 3: PERSONAL TAXES UNDER THE CONSUMPTION TAX}

\begin{tabular}{|l|c|c|c|c|c|}
\hline & Earnings & $\begin{array}{c}\text { Saving } \\
\text { (negative } \\
\text { implies a } \\
\text { withdrawal) }\end{array}$ & $\begin{array}{c}\text { Income Available } \\
\text { to Pay for } \\
\text { Consumption by } \\
\text { Saver }\end{array}$ & $\begin{array}{c}\text { Sales Tax } \\
\text { Paid by } \\
\text { a Saver }\end{array}$ & $\begin{array}{c}\text { Sales Tax } \\
\text { Paid by } \\
\text { Consumer } \\
\text { (no saving) }\end{array}$ \\
\hline Year 1 & $\$ 20,000$ & $\$ 5,000$ & $\$ 15,000$ & $\$ 3,750$ & $\$ 5,000$ \\
Year 2 & $\$ 20,000$ & $-\$ 5,500$ & $\$ 25,500$ & $\$ 6,375$ & $\$ 5,000$ \\
Undiscounted & & & $\$ 10,125$ & $\$ 10,000$ \\
Discounted Tax & & & $\$ 9,545$ & $\$ 9,545$ \\
\hline
\end{tabular}

Notes:

In this table, either a person saves \$5,000 during Year 1 and uses the savings plus interest (paid at a rate of 10 per cent) to consume in Year 2, or the person saves nothing at all (spending $\$ 20,000$ each year). The consumption tax rate is 33 per cent on goods and services (this is equivalent to a 25-per-cent consumption tax on earnings used to buy goods and services subject to sales taxation). In the first year, the tax base is only $\$ 15,000$ since $\$ 5,000$ is contributed to a registered account. The taxpayer pays only \$3,750 in consumption tax in Year 1. In Year 2, the tax base is much larger - $\$ 25,500$ - as it is assumed that the taxpayer withdraws all the principal and interest that year $(\$ 5,500)$ which is added to $\$ 20,000$ in earnings. The total tax paid in Year 2 is $\$ 6,375$. On an undiscounted basis, the tax paid in the two years is $\$ 10,125$. The discounted value (discount Year 2 by 10 per cent) is $\$ 9,545$. Note if a person does not save, using $\$ 20,000$ to buy taxed goods and services in both years, the sales tax paid in each year is $\$ 5,000$. While the timing of taxes differs from the previous approach, the discounted tax paid (at an interest rate of 10 per cent) is the same under both approaches: \$9,545 in total.

9 An alternative approach to consumption taxes is to adjust the personal tax base to reflect expenditure rather than income. One adjustment is to collect the tax on earnings net of saving (contributions to retirement-savings plans are fully deducted from earnings, no tax is imposed on investment income earned in the plan, and withdrawals from accounts for consumption are fully taxed as in the case of registered pension plans and RRSPs). Another approach is to apply no tax on investment income earned, as in the case of tax-free savings accounts. In both cases, borrowed financing costs incurred to fund investments are not deductible. We discuss these approaches to consumption taxes below with regard to alternatives to a general sales tax. 
Consumption taxation, of which the GST is a variant, has a number of distinct advantages. Perhaps, the most important is the argument that people's enjoyment of current and future consumption is an appropriate measure for taxation. Certainly, a consumption tax does not discriminate between savers and consumers. This minimizes the harmful effect of taxation that discourages wealth accumulation for future consumption as well as achieving horizontal equity (equal treatment of consumers and savers). An annual income tax discriminates against future consumption since capital income earned to generate future consumption is taxed in addition to earnings resulting in the double-taxation of savings.

Further, for those who argue that individuals may not anticipate future needs and insufficiently save for the future, a consumption tax is preferable to an income tax by removing the tax on the return to saving.

Many of the hard-to-make calculations under the comprehensive income tax are avoided, such as indexation for inflation, asset depreciation, imputed income from consumer durables and capital gains. Given the difficulties inherent with annual income taxation, sales taxation is simpler even though businesses must comply with the sales-tax rules and regulations that give rise to other complexities. ${ }^{10}$

While these advantages to sales taxation are important, several criticisms have been made against using consumption solely as a tax base. One criticism is that not all saving is used for future consumption, but rather, is left as a bequest for heirs. Thus, sales taxation does not tax fully such consumption. For this reason, some have argued for a special tax on estate and gift transfers to ensure that consumption of this sort is also taxed. Alternatively, wealth accumulations should be subject to personal income taxes for high-income households.

Another criticism is that consumption taxes apply to a narrower tax base than annual income by exempting saving. This requires the sales tax to be assessed at a higher rate than an income tax to raise the same revenue, thereby discouraging work effort more heavily. An argument to applying some tax on investment income is that it reduces the tax distortion on work effort since the tax base could be broader.

While these critiques of expenditure taxation would provide a basis for taxing the return to saving, they do not present a clear argument in favour of comprehensive income taxation that would require both consumption and saving to be taxed at equal rates. As an observation, most countries have effectively chosen to provide some saving exemptions and lower tax rates on investment income compared to earnings. In Canada, households pay no personal income tax on investment income in the case of tax-assisted pension and retirement saving plans (RRSPs, registered pension plans and tax-free savings accounts), home ownership (principal residence) and other consumer durables. The current personal "income tax" is a hybrid of consumption and comprehensive income taxation.

10 For example, under the GST, financial services are exempt from the sales tax. Complex rules have been developed to delineate between taxable and tax-exempt goods and services particularly with respect the awarding of input tax credits to relieve taxes on business-to-business sales. 


\section{Economic Gains to Alberta with Increased Reliance on Consumption Taxes}

The specific argument for increased consumption taxes in Alberta rests on economic gains from less-harmful taxation to the economy. Economists have measured the economic cost of raising an additional dollar of revenue from a particular source. This cost is one dollar plus the economic loss arising from discouraging work effort, investment or risk-taking. The key point is that the economic cost of raising incremental tax revenues increases with the size of the tax rate as well as its impact on reducing the tax base.

Dahlby and Ferede ${ }^{l 1}$ have estimated the marginal cost of raising sales, personal and corporate taxes in Canada for the federal and provincial governments. The marginal cost of a tax, or $\mathrm{MCF}$, is the marginal economic cost in dollars for every dollar of tax revenue raised. The economic cost arises from reducing economic activity due to taxation. Their results for Alberta are quite striking. Taking into account the economic distortions of raising taxes, the long-run marginal cost of raising a dollar is $\$ 81.61$ for corporate income taxes ${ }^{12}$ and $\$ 1.44$ for personal income taxes in 2011. The marginal cost of raising a dollar of a general sales tax in Alberta is lowest at $\$ 1.00$, due to its current absence.

Other estimates of the dynamic cost of corporate taxation are smaller than the Dahlby-Ferede results since they are focused on corporate taxation at the national level and typically exclude the impact of profit-shifting that reduces the amount of revenue raised when corporate income tax rates are raised. These other studies suggest that the dynamic economic cost is at least $\$ 1.40$ for each dollar of corporate taxes raised by governments. ${ }^{13}$

No tax is without some cost, but consumption taxes have a smaller economic effect. Although sales taxes raise consumer prices, thereby reducing the amount of goods and services that can be purchased by Albertans with their earnings from work effort, sales taxes apply equally to current and future consumption, thereby imposing no tax on saving. Unlike income taxes, consumption taxes do not reduce the yield people receive on their investments, thereby allowing Albertans to more quickly accumulate wealth for the future. It is therefore not surprising that many jurisdictions around the world have shifted to consumption-based taxation, especially the value-added tax, in the past half century.

11 B. Dahlby and E. Ferede, "The Marginal Cost of Raising Tax Revenue: Implications for Tax Policy Options in Alberta," prepared for Imagining Alberta: Symposium on Alberta's Economic Future, University of Alberta, 2011.

12

Dahlby and Ferede take into account profit-shifting by companies when the corporate income tax is raised. For a province, the increased revenue from additional corporate taxation is much smaller when such profit-shifting is included in revenue estimates. Thus, a small increase in the corporate income tax rate reduces investment but raises only some revenue.

13 See: B. Hamilton, J. Mintz and J. Whalley, "Decomposing the Welfare Costs of Capital Tax Distortions: The Importance of Risk Assumptions," National Bureau of Economic Research, Working Paper No. 3628, 1991; D. Jorgenson, and K-Y Yun, Investment Volume 3: Lifting the Burden: Tax Reform, the Cost of Capital and U.S.

Economic Growth (Cambridge, Mass.: The MIT Press, 2002); and M. Baylor, and L. Beauséjour, "Taxation and Economic Efficiency: Results from a Canadian CGE Model," Working Paper 2004-10, Department of Finance, Ottawa, 2004. 
A clear economic gain arising from increased reliance on consumption over income taxes is the reduction of levies on savings and capital investment. The inter-temporal distortion - the tax affecting future consumption relative to current consumption - imposes a significant economic cost on the economy. A revenue-neutral shift from income to consumption taxes, however, could increase the tax rate on work effort and therefore increase distortions in the labour market. However, labour income is less sensitive to tax changes than is investment and saving overall, the economy gains by shifting to a greater reliance on consumption taxes..$^{14}$

\section{Impact on Personal Saving and Portfolio Decisions}

Albertans save for their personal needs, such as ensuring adequate retirement and covering unexpected contingencies. To maximize the return on saving, Albertans will invest in a portfolio of assets that provide a maximal return given the risk that they wish to tolerate. Many entrepreneurial Albertans also invest in their own businesses to provide a livelihood for themselves and those who work for the business.

In recent years, the federal and Alberta governments have reduced taxes on saving with a more generous treatment of retirement saving through expanded limits and the introduction of the tax-free savings account. Thus, a significant amount of saving, to the extent that funds are invested in tax-assisted investments, is not subject to tax. Nonetheless, despite the availability of tax-assisted plans, incremental saving is subject to personal income taxation at most income levels since households are not always able to shelter saving from tax due to the lack of liquidity, shelter limits, ${ }^{15}$ or rather because they expect that withdrawals from tax-assisted saving plans will be taxed at high rates in the future.

As shown in Table 4, a significant share of household income (dividends, capital gains and other investment income) is derived from taxable investments that have not been invested in tax-exempt savings plans. Even for low-income households, almost five per cent of household income includes taxable investment income. Thus, a shift on income to sales taxes would benefit those taxpayers whose incremental saving is subject to taxation.

TABLE 4: HOUSEHOLD INVESTMENT INCOME (DIVIDENDS, CAPITAL GAINS AND OTHER INVESTMENT INCOME) SUBJECT TO PERSONAL INCOME TAXATION IN ALBERTA (2013)

\begin{tabular}{|l|c|c|}
\hline Income Brackets & Investment Income (\$ million) & $\begin{array}{c}\text { Proportion of Household } \\
\text { Income }\end{array}$ \\
\hline$\$ 20,000-40,000$ & $\$ 363$ & $5.03 \%$ \\
$\$ 40,000-60,000$ & $\$ 485$ & $5.18 \%$ \\
$\$ 60,000-80,000$ & $\$ 476$ & $3.37 \%$ \\
$\$ 80,000-100,000$ & $\$ 906$ & $5.82 \%$ \\
$\$ 100,000-200,000$ & $\$ 3,472$ & $5.05 \%$ \\
$\$ 200,000+$ & $\$ 11,555$ & $17.29 \%$ \\
All & $\$ 17,268$ & $9.43 \%$ \\
\hline
\end{tabular}

Source: Statistics Canada model SPSD/M.

\footnotetext{
14 See M. Baylor and Louis Beauséjour, "Taxation and Economic Efficiency: Results from a Canadian CGE Model," Working Paper 2004-10, Finance Canada, Ottawa, November 2004.

15 One important limit is with respect to "earned income": A taxpayer cannot deduct contributions to RRSPs if contributions are more than 18 per cent of employment and self-employed income. This can be important when a taxpayer receives a gift or inheritance, for example.
} 
The existing income tax system also distorts portfolio decisions made by investors, choosing between investments in equities or bonds. Income earned from investments in bonds is fully taxed at prevailing rates. Dividends and capital gains are taxed at low rates with the purpose of offsetting corporate-profit taxes that reduce income available for distributions to shareholders or reinvestment (such reinvestment gives rise to capital gains on shares from increased valuation). Given that capital gains are assessed only when an investor disposes of assets, the capital gains tax also results in a "lock-in effect" whereby individuals hold assets for a longer period to avoid triggering taxes.

As shown in Table 5 below, the combined federal-provincial corporate and top personal statutory tax rates on income derived from equity and ordinary income (such as interest on bonds) varies substantially, thereby distorting portfolio choices. Ordinary income at the top federal-Alberta personal income tax rate is subject to a rate of 39 per cent. Dividends and capital gains derived from equity investments in large- and medium-sized corporations is roughly taxed at the same rate, taking into account both corporate income taxes (a tax rate of 25 per cent on profits) ${ }^{16}$ plus personal taxes on dividends and capital gain realizations. ${ }^{17}$ For equity investments held in small businesses, corporate and personal income tax rates are least for capital gains, which are most favourably treated.

TABLE 5: COMBINED CORPORATE AND PERSONAL INCOME TAX RATES ON EQUITY AND OTHER INVESTMENT INCOME IN ALBERTA (TOP RATE AS OF 2013)

\begin{tabular}{|l|c|c|c|c|c|}
\hline & $\begin{array}{c}\text { Dividends } \\
\text { (Large Corp) }\end{array}$ & $\begin{array}{c}\text { Capital Gains } \\
\text { (Large Corp) }\end{array}$ & $\begin{array}{c}\text { Dividends } \\
\text { (Small Corp) }\end{array}$ & $\begin{array}{c}\text { Capital Gains } \\
\text { (Small Corp) }\end{array}$ & $\begin{array}{c}\text { Ordinary } \\
\text { Income }\end{array}$ \\
\hline Profit & $\$ 100$ & $\$ 100$ & $\$ 100$ & $\$ 100$ & $\$ 100(a)$ \\
Corporate Tax & $\$ 25$ & $\$ 25$ & $\$ 14$ & $\$ 14$ & $\$ 0$ \\
Net Payment & $\$ 75$ & $\$ 75$ & $\$ 86$ & $\$ 86$ & $\$ 100$ \\
Personal Tax & $\$ 14.5(b)$ & $\$ 14.6(d)$ & $\$ 23(c)$ & $\$ 16.8(d)$ & $\$ 39$ \\
After-tax Income & $\$ 60.5$ & $\$ 60.4$ & $\$ 62.2$ & $\$ 69.2$ & $\$ 61$ \\
\hline
\end{tabular}

Notes:

(a) Refers to interest, salary, rents or royalty paid by corporation to an investor. Such payments are deductible from corporate profits and are not taxable at the corporate level.

(b) The tax rate on eligible dividends is calculated as personal tax rate on taxable dividends (grossed-up value of actual dividends received) minus the dividend tax credit. For eligible dividends (corporate income taxed at high corporate rate), taxable dividends are grossed up by 38 per cent. The federal-provincial combined dividend tax credit is 25.02 per cent of taxable dividends. The effective personal tax rate on eligible dividends is 19.29 per cent in Alberta for an investor taxed at the top personal tax rate of 39 per cent.

(c) For ineligible dividends (dividends paid by Canadian-controlled private corporations from profits less than $\$ 500,000$ ), the federal-provincial dividend tax credit is 16.83 per cent of taxable dividends. The effective federal-provincial personal income tax rate on ineligible dividends is 27.71 per cent for investors at a 39-per-cent personal tax rate.

(d) Capital gains arising from the disposal of shares are taxed at half the personal tax rate for both large and small firms (for calculations it is assumed one dollar of reinvested profits results in one dollar of capital gain income).

16 The average corporate tax rate on profits could be more or less than 25 per cent after taking into account differences between taxable income and accounting income of the corporation. We take the statutory tax rate to be equal to the effective average tax rate.

17 Note that the effective capital gains tax is less than the capital gains tax on realizations after accounting for the deferral of capital gains taxes when assets are held for longer than a year. For example, taking into account deferral, an effective (accrual-equivalent) capital gains tax rate would be roughly half of the capital gains tax on realizations if the discount rate is 10 per cent and the time period for shares held by an investor is 20 years. 
The implications drawn from Table 5 is that the income tax system imposes some important distortions on portfolio choices made by Albertans. Shares with low dividend yields are taxed least, after taking into account the deferral of capital gain taxes. Dividend income derived from large- and medium-sized businesses are roughly taxed at the same rate after accounting for both corporate and personal income taxes. Adding to this list of distortions is the lock-in effect of capital gains taxes that impedes Albertans from reallocating their portfolios from poor to better investments.

Overall, a case can be made for a shift from income to consumption taxes to reduce the inherent distortions in the personal income tax system with respect to the treatment of capital income. Although one could try to improve taxation of portfolio-investment income to establish a more equal playing field, it is not easy to do so given the near impossibility of taxing comprehensive income fully, as discussed above.

\section{Impact on Business Investment}

As discussed above, the corporate tax is the most economically harmful tax due its impact on investment and the loss of revenues when companies shift profits out of Alberta.

When it comes to the taxation of business investments, Alberta has little tax advantage in attracting capital. Effective tax rates on new investment in Alberta's non-resource sectors are in the middle of the pack among OECD jurisdictions. ${ }^{18}$ Once accounting for the distortionary impacts of oil and gas royalties, the oil and gas industry is more heavily taxed on marginal projects than are other industries in Alberta, including oil sands investments. ${ }^{19}$

Table 6 shows that Alberta's effective tax rate on new investments in non-resource sectors is about the same as the OECD average in 2012, taking into account corporate income taxes, sales tax on capital purchases and other capital-related taxes such as taxes on fixed assets. Alberta has the 22nd highest effective tax rate on new investment among 44 OECD countries and Canadian provinces. The Atlantic provinces and Quebec have lower effective tax rates on new investment compared to Alberta due to the federal Atlantic Investment Tax Credit and provincial tax incentives primarily aimed at forestry and manufacturing. Ontario's is not that much above that of Alberta. Overall, Alberta is neither high- nor low-tax with regard to attracting capital from other Canadian or international jurisdictions.

Further, the corporate income tax rate in Alberta is 25 per cent for large- and medium-sized businesses. The corporate income tax rate, not much different than the world average for manufacturing and service companies, not only increases the tax cost of investment but also the degree to which companies will structure their financing and transfer prices to affect the amount of corporate tax paid in different jurisdictions. Companies shift profits from jurisdictions with high corporate income tax rates to those with lower corporate income tax rates without necessarily changing their capital and production decisions. As other countries, such as the United Kingdom and Denmark, have been reducing their corporate tax rates closer to 20 per cent, multinationals have an incentive to shift corporate profits from Alberta to

\footnotetext{
18 See D. Chen and J. Mintz, “ 2012 Annual Global Tax Competitiveness Ranking: A Canadian Good News Story,” University of Calgary, School of Public Policy, SPP Research Papers 5, 28 (2012).

19 See J. Mintz and D. Chen, "Capturing Economic Rents of Resources Through Royalties and Taxes," University of Calgary, School of Public Policy, SPP Research Papers 5, 30 (October 2012).
} 
foreign jurisdictions with lower statutory corporate income tax rates. Therefore, when the corporate income tax rate is reduced in Alberta, not only is investment encouraged, but revenue cost is also lessened when fewer profits are shifted out of Alberta. ${ }^{20}$

TABLE 6: EFFECTIVE TAX RATES ON CAPITAL FOR CANADIAN PROVINCES, RANKED AMONG THE OECD COUNTRIES 2005-12

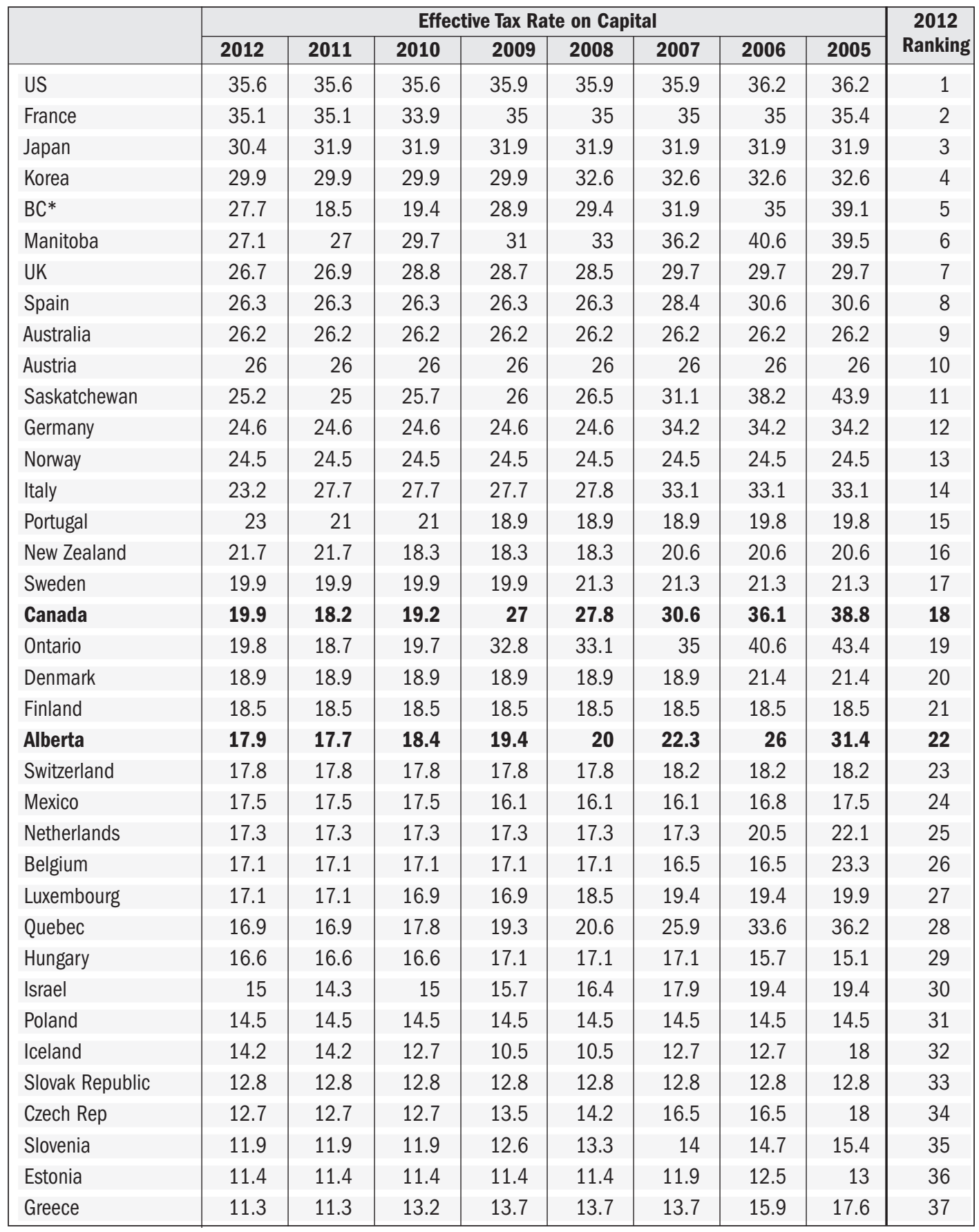

${ }^{20}$ See the discussion on income-shifting studies and corporate tax revenues that have remained constant as a share of GDP in Canada despite corporate income tax rate reductions since 2000. B. Dahlby and E. Ferede, "The Marginal Cost of Raising Tax Revenue: Implications for Tax Policy Options in Alberta," prepared for Imagining Alberta:

Symposium on Alberta's Economic Future, University of Alberta, 2011. 
TABLE 6: EFFECTIVE TAX RATES ON CAPITAL FOR CANADIAN PROVINCES, RANKED AMONG THE OECD COUNTRIES 2012-13 (cont'd)

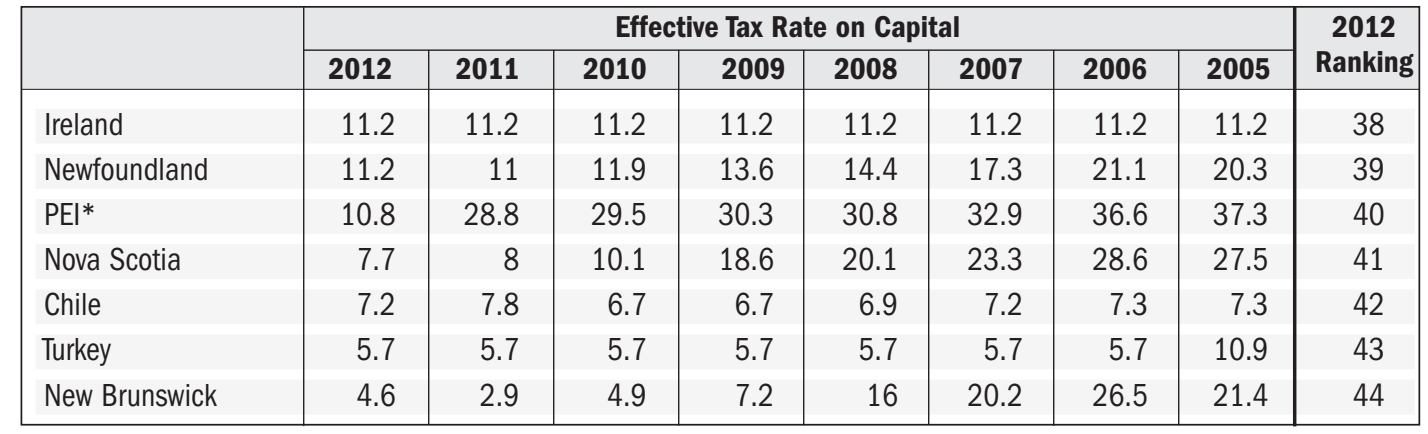

* Assumes legislated changes after 2012 are incorporated in 2012 investment decisions.

Source: D. Chen, Walton Tax and Economic Growth Program, The School of Public Policy.

Although Alberta does not stray far from worldwide practice, its corporate tax is quite distortionary with tax rates sharply varying by asset, size of firm and industry, as illustrated in Table 7. New investments in construction and services, including utilities, communications, transportation and other services, are more highly taxed than agriculture, forestry and manufacturing in Alberta. Businesses that are more intensive in their use of inventories and machinery capital bear more tax. Medium-sized and large businesses are more heavily taxed than small businesses due to differences in corporate income tax rates.

Reducing differences in tax burdens across business would contribute to better productivity with a more neutral treatment of business activities. Even just a reduction in the general corporate income tax rate of 10 per cent reduces the disparity in effective tax rates across industries, assets and different-sized firms. A level-playing field among businesses would result in a shift of resources to sectors with higher pre-tax returns on investments away from those with lower ones.

TABLE 7: EFFECTIVE TAX RATES ON NEW INVESTMENT BY INDUSTRY, ASSETS AND SIZE FOR 2013

\begin{tabular}{|l|r|r|r|r|r|r|r|r|r|r|r|}
\hline & Agriculture & Forestry & $\begin{array}{c}\text { Electrical } \\
\text { Power, Gas } \\
\text { \& Water }\end{array}$ & $\begin{array}{l}\text { Construc- } \\
\text { tion }\end{array}$ & $\begin{array}{c}\text { Manufac- } \\
\text { turing }\end{array}$ & $\begin{array}{l}\text { Wholesale } \\
\text { Trade }\end{array}$ & $\begin{array}{c}\text { Retail } \\
\text { Trade }\end{array}$ & $\begin{array}{c}\text { Transport } \\
\text { and } \\
\text { Storage }\end{array}$ & $\begin{array}{r}\text { Commu- } \\
\text { nication }\end{array}$ & $\begin{array}{c}\text { Other } \\
\text { Services }\end{array}$ & Aggregate \\
\hline LARGE AND & & & & & & & & & & & \\
MEDIUM & & & & & & & & & & & \\
Buildings & $18.6 \%$ & $22.8 \%$ & $18.3 \%$ & $18.9 \%$ & $26.5 \%$ & $20.9 \%$ & $21.7 \%$ & $16.6 \%$ & $20.1 \%$ & $20.1 \%$ & $21.0 \%$ \\
Machinery & $20.0 \%$ & $-2.9 \%$ & $19.9 \%$ & $20.5 \%$ & $-2.6 \%$ & $16.6 \%$ & $19.6 \%$ & $17.2 \%$ & $19.0 \%$ & $19.9 \%$ & $14.5 \%$ \\
Land & $10.1 \%$ & $10.1 \%$ & $10.1 \%$ & $10.1 \%$ & $10.1 \%$ & $10.1 \%$ & $10.1 \%$ & $10.1 \%$ & $10.1 \%$ & $10.1 \%$ & $10.1 \%$ \\
Inventory & $10.1 \%$ & $23.2 \%$ & $23.2 \%$ & $23.2 \%$ & $23.2 \%$ & $23.2 \%$ & $23.2 \%$ & $23.2 \%$ & $23.2 \%$ & $23.2 \%$ & $23.2 \%$ \\
Aggregate & $16.6 \%$ & $9.6 \%$ & $17.2 \%$ & $21.0 \%$ & $13.1 \%$ & $20.1 \%$ & $20.4 \%$ & $16.6 \%$ & $18.8 \%$ & $18.7 \%$ & $17.0 \%$ \\
SMALL & & & & & & & & & & & \\
Buildings & $14.0 \%$ & $15.1 \%$ & $16.2 \%$ & $12.5 \%$ & $16.8 \%$ & $13.7 \%$ & $14.6 \%$ & $11.7 \%$ & $13.5 \%$ & $13.3 \%$ & $13.6 \%$ \\
Machinery & $12.0 \%$ & $7.0 \%$ & $14.9 \%$ & $14.3 \%$ & $4.0 \%$ & $12.0 \%$ & $13.7 \%$ & $12.3 \%$ & $13.8 \%$ & $11.1 \%$ & $11.4 \%$ \\
Land & $6.9 \%$ & $6.9 \%$ & $6.9 \%$ & $6.9 \%$ & $6.9 \%$ & $6.9 \%$ & $6.9 \%$ & $6.9 \%$ & $6.9 \%$ & $6.9 \%$ & $6.9 \%$ \\
Inventory & $6.9 \%$ & $15.3 \%$ & $15.3 \%$ & $15.3 \%$ & $15.3 \%$ & $15.3 \%$ & $15.3 \%$ & $15.3 \%$ & $15.3 \%$ & $15.3 \%$ & $15.1 \%$ \\
Aggregate & $11.1 \%$ & $9.0 \%$ & $13.8 \%$ & $14.3 \%$ & $9.8 \%$ & $13.8 \%$ & $13.8 \%$ & $10.8 \%$ & $13.7 \%$ & $11.3 \%$ & $12.1 \%$ \\
\hline
\end{tabular}


Overall, economic studies suggest some significant gains by achieving a more level playing field among businesses. Corporate taxes distort decision-making with respect to the choice of assets, industries and form of organization (static effects) and, as discussed above, investment (dynamic effects). As a rough guide based on global studies, the static economic cost of corporate taxation (leaving aside important inter-temporal distortions) is in the range of 50 to 85 cents per dollar of revenue. ${ }^{21}$

Thus, a reduction in the corporate tax rate would reduce disparities in effective tax rates across business activities and result in a more productive economy. It would not only increase the incentive to invest in Alberta, but also help reduce the distortions in the corporate tax system. It would help retain corporate profits in Alberta, providing more revenue to the Alberta government. Lower corporate income tax rates would therefore result in both static and dynamic efficiency gains for Alberta's economy.

A shift from corporate income taxes to a sales tax would also improve economic growth. One estimate $^{22}$ suggests that a reduction in the corporate income tax rate by five percentage points in favour of the introduction of an Alberta HST of equal revenue would increase economic output per capita by 30 per cent within 25 years (output per capita would increase 48 per cent within a century). Thus, most of the economic gain resulting from any tax-mix shift from corporate taxes to the HST would be within two decades.

\section{Collecting More Tax Revenue from Non-Residents}

Many workers, family, friends and tourists come to Alberta as non-residents, enjoying the quality of infrastructure and other services provided by the Alberta government. One of the advantages of a sales tax, as opposed to personal income taxation, is that governments obtain additional revenues provided by non-residents to help fund public services, such as infrastructure, that is beneficial to non-resident consumers visiting the province.

In our analysis, we estimate that approximately 10 per cent of a general sales tax in the form of the HST would be collected from non-residents. ${ }^{23}$ Some of the tax would be shifted forward to consumers, while some may be shifted back to tourist operators and landowners.

21 The static economic costs of corporate taxation can be significant due to impacts on the choice of assets, industries and organizational form. For various estimates, see: J. Gravelle and L. Kotlikoff, "The Incidence and Efficiency Cost of Corporate Taxation when Corporate and Non-Corporate Forms Produce the Same Good," WP/88/32, Washington D. C. International Monetary Fund, 1988; and B. Hamilton, J. Mintz and J. Whalley, "Decomposing the Welfare Costs of Capital Tax Distortions: The Importance of Risk Assumptions," National Bureau of Economic Research, Working Paper No. 3628, 1991; and Jorgenson and Yun, Investment Volume 3: Lifting the Burden: Tax Reform, the Cost of Capital and U.S. Economic Growth.

22 B. Dahlby and E. Ferede, "The Impact of Tax Cuts on Economic Growth: Evidence from the Canadian Provinces," National Tax Journal 65, 3 (2012) 563-94.

23 We thank Duanjie Chen for these calculations. They are based on data taken from domestic tourism spending (Statistics Canada Cansim Table 4260015: Travel survey of residents of Canada, travel characteristics, by province of destination, annually (Person-trips) and Cansim Table 4260017: Travel survey of residents of Canada), reallocated expenditures, by travel characteristics, annually (Dollars). Non-resident Canadian travel to (2006-2010) is 12.9 per cent. Applying these Alberta ratios, as a proxy, to the total domestic tourism expenditures in year 2011, the resultant Alberta tourism expenditure by domestic non-Albertan travellers in Alberta is approximately $\$ 7$ billion. For allocating the tourism demand/spending by foreign visitors, Alberta's share is estimated to be 5.2 per cent of total "non-resident tourists" (Statistics Canada Cansim Table 4270004: Number of international tourists entering or returning to Canada, by province of entry, monthly (Persons)). Applying this ratio to the 2011 "tourism export," which is about $\$ 13$ billion, yields Alberta's tourism export, or foreign demand of tourism in Alberta, of \$682 million for 2011. Therefore, the total potential HST base associated with non-Albertan taxpayers is about $\$ 7.7$ billion in 2010. With the proposed provincial HST rate of eight per cent, the potential HST revenue payable by non-Albertans would be roughly above $\$ 0.611$ billion, which is about 10 per cent of 2010 HST payments. 
A sales tax could discourage non-resident consumption of goods and services in Alberta, although the precise effect is not known. Tourism is less sensitive to locations with strong appeal (e.g., Venice or Banff) compared to those that have close competing alternatives (beaches). Studies suggest that destination prices have less impact on tourism than exchange rates and transportation costs. Studies also suggest that an increase in destination prices would reduce tourism to some extent, depending on the quality of the destination (a 10-per-cent increase in destination prices would reduce tourism ranging from five per cent to 14 per cent). ${ }^{24}$ Demand by non-residents working in Alberta temporarily for Alberta goods and services would probably be less sensitive to price shifts.

The HST in Alberta would therefore result in additional taxes on non-resident consumption in Alberta. However, by shifting from personal income taxes to the HST, Albertans will pay less tax on the income they earn to purchase foreign consumption goods (including those related to Albertans travelling abroad). Alberta could also lose income tax and other revenues from any net reductions in Alberta business activity due to tourism (although resources not used in the tourism sector can be used elsewhere in the economy).

While general sales-tax revenues paid by non-residents would be affected by less tourism, the revenues would be used to support Albertan public or private incomes in other ways. We will discuss alternative uses of this revenue obtained from non-resident consumption as part of our proposals for tax reform.

\section{Reducing Volatility in Alberta's Revenue}

With the Alberta government own-source revenues depending significantly on natural resource revenues (Table 1), Alberta's revenues are therefore highly volatile. As a result, surpluses quickly build up with rising energy prices, while deficits appear when prices fall.

This imposes a large degree of risk on fiscal planning, especially when a government must balance its budget as required by legislation in Alberta. In downturns, the government must cut spending when revenues come up short. In upturns, spending spigots may be turned on as revenues pour into government coffers. While good fiscal planning with built-up stabilization funds can help mitigate spending sprees and cutbacks, other actions can be taken to reduce volatility in Alberta's own-source revenues.

One risk-management approach is to shift reliance to less volatile revenues sources. In recent years, the Alberta government has done the opposite, eliminating the Alberta health premium and a planned alcohol levy in 2008. The Alberta health-care premium was one of the least volatile sources among provincial own-source revenues.

24 G. Crouch, "A Meta-analysis of Tourism Demand," Annals of Tourism Research, 22, 1 (1995) 103-118. 
TABLE 8: VOLATILITY OF REVENUE SOURCES IN ALBERTA

\begin{tabular}{|l|c|}
\hline Alberta Government Revenue 1991-2009 & Coefficient of Variation* \\
\hline Own-Source Revenue & $11.20 \%$ \\
Personal Income Tax & $14.60 \%$ \\
Corporate Income Tax & $16.50 \%$ \\
Natural Resource Revenue & $36.30 \%$ \\
GST/HST & $10.70 \%$ \\
\hline
\end{tabular}

Note: The coefficient of variation is measured as the standard deviation of differences from a trend, divided by the mean of a data series.

A shift from income taxes to consumption taxes like the HST (which has a similar base to the GST) would reduce, to some degree, volatility in Alberta's revenue stream. As shown in Table 8, the GST/HST revenue stream in Alberta is less volatile than personal and corporate taxes, as well as the aggregate of own-source revenues as measured by the coefficient of variation. ${ }^{25}$

\section{Minimizing the Impact on Administrative and Compliance Costs}

Taxes not only impose economic costs by discouraging work effort, risk-taking, investment and saving, but they can also be costly to collect. Governments must hire bureaucracies and buy equipment to collect taxes (administrative costs) and taxpayers must hire accountants, lawyers and develop systems to comply with the tax system. According to one recent study, administrative and compliance costs associated with tax collection in Canada accounted for 4.5 to five per cent of total tax revenues in 2011. ${ }^{26}$ Total administrative costs in Canada are \$6.6 billion, individual tax compliance costs are $\$ 4.7$ to $\$ 7$ billion, and business tax compliance costs range from $\$ 14.5$ to $\$ 17.8$ billion.

By far, personal and corporate taxes account for the lion's share of tax administrative and compliance costs. In this regard, Canadian tax collection agreements between federal and provincial governments reduce both administrative and compliance costs. Alberta has a tax collection agreement with the federal government for personal income taxes, but not for corporate income tax. When Ontario harmonized its corporate income tax with the federal government, one study suggested that corporate tax compliance would decrease by $\$ 137$ million annually, with 90 per cent of compliance cost savings benefiting small businesses. ${ }^{27}$

25 The coefficient of variation is measured as the standard deviation of differences from a trend, divided by the mean of a data series. In this case, the differences were taken from an exponential trend for each revenue source, and the mean (average) revenue of each source is taken for the same period, 1991-2009. Note that our estimates vary from S. Langdon and C. Smith, "Energy Prices and Alberta Government Revenue Volatility," C.D. Howe Institute Commentary 313 (2010), as the data series used in our analysis includes more recent data that has since been made available.

${ }^{26}$ See: F. Vaillancourt, É. Roy-César and M. S. Barros, "The Compliance and Administrative Costs of Taxation in Canada," The Fraser Institute, Studies in Tax Policy (April 2013). The authors estimate that total compliance and administrative costs in Canada are 1.5 to 1.8 per cent of GDP. Here, we convert costs to be a proportion of tax revenues, which is about a third of GDP.

27 PriceWaterhouseCoopers, "Corporate Tax Administration in Ontario (CTAO): A Study of Compliance Cost Savings," prepared for the Canada Revenue Agency, 2009. 
Bringing in a new form of taxation would typically increase the costs of compliance and administration. However, if the HST were adopted in Alberta, compliance costs would not increase significantly since businesses already pay the federal GST - there would simply be a change in the rate of tax. There would be some additional compliance and administrative costs if Alberta introduced point-of-sale rebates for specific goods and services as in Ontario and the Atlantic provinces. Further, some additional administrative costs for the Alberta government would be incurred to administer its own HST, which would not be substantial if there were a sales-tax collection agreement with the federal government.

\section{Consumption Tax Options: The Case for the HST}

If Alberta wished to increase consumption taxes as a partial replacement for personal income taxes, several alternatives are available:

- Increasing user fees for public services such as a health premium for medicare services.

- Increasing or introducing selective excise taxes related to consumption such as alcohol, tobacco, fuel, amusement and luxury-good taxes.

- Adjusting the personal income tax to apply to expenditure.

- Introducing a business value tax.

- Introducing a retail sales tax akin to the other three western provinces.

- Introducing an Alberta Harmonized Sales Tax (HST).

Alternative tax proposals are evaluated in terms of efficiency, equity and simplicity, reviewed here in turn.

\section{USER FEES}

Greater reliance on user fees is certainly a possible alternative. Alberta is expected to raise $\$ 3.5$ billion in user fees this fiscal year, which is less than 10 per cent of the current budget (Table 1). Examples of user fees that fund public services are tolls, transit fares, post-secondary tuition payments and payments for infrastructure costs.

User fees were a greater part of its revenue collection until Jan. 1, 2009 when the Alberta Health Premium was eliminated. In its final year, it provided the Alberta government $\$ 1.3$ billion. Although criticized as a regressive tax, the premium was subsidized for lower-income households. The tax was both a stable and relatively non-distorting source of revenue. It would have been a more effective source of revenue had the premium been related to patient demand for health-care services as recommended by the Mazankowski and Graydon task forces a decade ago. ${ }^{28}$

28 See: D. Mazankowski, A Framework for Reform: Report of Premier's Advisory Council on Health, Alberta Health and Wellness, 2001; and D. Graydon, A Sustainable Health System for Alberta: Report of the M.L.A. Task Force on Health Care Funding and Revenue Generation, Alberta Health and Wellness, October 2002. 
User fees are arguably fair in that those Albertans who use the public services pay for them. They can be efficient by specifically pricing the services themselves. On the other hand, user fees are set by a government to recover costs and insufficient pressure may be put on government to keep service costs low given the lack of competition by other suppliers. Further, user fees are regressive, although the impact can be ameliorated by low-income tax credits under the personal income tax. It is unlikely that new user fees would be a significant source of new revenues, but they could provide limited new revenues to the Alberta government.

\section{EXCISE TAXES}

Alberta currently raises less than $\$ 5$ billion in excise taxes, including "sin" taxes on alcohol, tobacco and gambling, as well as other goods and services including insurance, fuel and tourism. Excise taxes could be broadened to include other goods and services such as luxury products (e.g., large automobiles, furs and jewelry). The fuel tax applied to gasoline and diesel could be broadened to tax other energy sources such as natural gas, coal and electricity. Environmental taxes such as emission fees and waste-management charges could also be expanded, including the existing Alberta carbon levy.

While new and expanded excise taxes could be a source of new revenue for Alberta, many apply not just to consumption but also to business costs. When applied to business inputs such as energy, Alberta businesses will be less competitive in international markets while capital investments are taxed more highly. Although excise taxes are used in many jurisdictions, it would be difficult for Alberta to set levies substantially higher than those of its neighbours for competitiveness reasons.

\section{A PERSONAL EXPENDITURE TAX}

Alberta could move towards a full expenditure tax by exempting the return on saving under the personal income tax. In principle, this would require no limits placed on funds invested in registered retirement saving plans, registered pension plans and tax-free savings accounts. The expansion of these tax-assisted savings plans would virtually eliminate most taxes paid on investment income. Alternatively, Alberta could introduce a 10-per-cent tax credit to relieve any taxes paid on investment income and capital gains on a limited basis (consistent with the existing tax collection agreement with the federal government).

Nonetheless, the adoption of a full personal expenditure tax would be problematic for three reasons. First, it would result in less revenue raised by the Alberta government and therefore a need to raise other taxes or income tax rates to recoup revenues. Second, any move to eliminating tax on investment income at the personal level would require adjustments to the business taxation that also falls on investment returns earned by Albertans through corporations and unincorporated businesses. Third, given that Alberta currently has a tax collection agreement with the government of Canada, the province agrees to follow the federal base, which requires the province to maintain the same limits as formulated by the federal government. Alberta could leave the tax collection agreement, but that would require Albertans to separately file their personal income tax forms, and for the Alberta government to administer the system. A full-blown Alberta expenditure tax would therefore be unappealing as a reform measure. 


\section{BUSINESS VALUE TAX}

Another form of consumption that Alberta could consider is a business value tax, or BVT, paid by businesses on revenues earned from the sale of goods and services less the cost of purchasing goods and services. ${ }^{29}$ No deduction would be provided for payroll and interest costs. Capital could be expensed from the base, making the tax more similar to a value-added tax. However, if the tax follows similar levies in Italy and Hungary, capital would be depreciated using rules similar to the corporate income tax. Effectively, the tax is then similar to a production tax on labour and capital services.

The BVT would be levied on goods and services sold within and outside the province.

Purchases from Alberta and non-Alberta businesses would be deducted from the base. Federal Crown corporations and First Nations businesses operating on reserves would not be taxable. The tax could be applied widely on profit and non-profit businesses, as in Italy.

Given the lack of experience in Canada with the BVT, Alberta would be a pioneer in adopting such a tax. The BVT could be a significant revenue source, although it would impose both administrative costs on the government and compliance costs on taxpayers. Administrative and compliance costs would be less if the tax were collected as part of the corporate income tax. Nonetheless, it could impose significant distortions on the economy if many producers were exempt.

\section{RETAIL SALES TAX}

Like British Columbia, Saskatchewan and Manitoba, Alberta could collect a retail sales tax that would be imposed on goods and some services on final sales to consumers. The tax would be new to Alberta and would require its own administration.

In recent years, the federal government encouraged provinces to reform their sales-tax systems by adopting a sales tax harmonized with the federal GST. All provinces east of the Manitoba border have replaced retail sales taxes with value-added taxes, which is explained in more detail in the next section.

The first problem with the retail sales tax is that a significant amount of its revenues are collected on commercial intermediate and capital inputs, since it is impossible to exempt business-to-business sales when many goods and services could also be used for consumption purposes (e.g., computers, automobiles, furniture, office supplies and structures). Given that a large share of retail sales-tax revenues apply to business inputs in many provinces, the tax harms both competitiveness and capital formation. ${ }^{30}$ Second, the retail sales tax typically exempts many services and therefore results in uneven effective tax rates on consumer products. Third, the retail sales tax would be a new tax with significant administrative and compliance costs.

\footnotetext{
29 This tax was proposed by R. Bird and J. Mintz in "Tax Assignment in Canada: A Modest Proposal," in Canada: The State and the Federation 1999/2000, Toward a Mission Statement for Canadian Fiscal Federalism, ed. Harvey Lazar (Kingston, Ont.: Queen's University, Institute of Intergovernmental Relations, 2000).

30 More than a third of Ontario retail sales taxes were levied on commercial intermediate and capital goods. See: P. Dungan, J. Mintz, F. Poschmann and T. Wilson, "Growth Oriented Sales Tax Reform for Ontario," C.D. Howe Institute Commentary 273, C.D. Howe Institute (September 2008).
} 
Overall, the retail sales tax would be a non-starter for improving the overall tax system for the province.

\section{THE HARMONIZED SALES TAX (HST)}

The best consumption tax option for Alberta is to adopt an HST, which would be piggybacked on the federal GST and therefore collected and administered by the federal government under a tax collection agreement. Albertans would see a higher sales-tax rate applied in the province, which would be added to the current GST rate of five per cent.

The GST and HST are forms of a credit-invoice value-added tax that is now used in over 140 jurisdictions around the world. The tax is applied to sales of goods and services sold by a business, which is able to claim an input tax credit for HST paid on purchases from other registered firms. Thus, the HST provides refunds of input taxes to avoid taxes on intermediate and capital goods and services purchased by businesses. The advantage of the HST is that it does not hurt business competitiveness and capital formation, as in the case of other consumption taxes discussed above. It also applies to a wide variety of goods and services, making the tax more efficient and fair compared to narrow-based consumption taxes such as the retail sales tax.

The federal GST has been criticized for three reasons. First, the current VAT in Canada is applied to a narrower base than it should be, collecting roughly half of potential revenues on consumption. ${ }^{31}$ This is unlike value-added taxes in some countries, such as New Zealand, that provide fewer exemptions of goods and services from tax. Second, a sales tax has been criticized as falling more heavily on the poor compared to the rich, although zero-rating of necessities (food, housing and medical supplies) and the low-income sales-tax credit has made the GST much less regressive, if it is at all. Given that saving is a deferral of consumption to the future, studies have shown that broad consumption taxes are proportional over lifetime incomes. Third, certain exemptions, especially for financial services, municipal, schools, hospitals and other non-profits, result in complexity as well as economic distortions.

We note that 77 per cent of the GST is paid directly by households in Alberta. Close to 13 per cent of the GST is paid by exempt businesses and non-profit organizations on their intermediate and capital inputs, with the remainder paid by non-residents as noted above. If the GST had fewer exemptions, households would directly pay more of the tax.

While it might be feasible for Alberta to design a better value-added tax than the current federal GST - something like the New Zealand GST - both administrative and compliance costs would be substantially reduced if Alberta adopted the HST.

For Alberta, the HST would therefore not impose a new tax on consumption as much as it would increase the rate of an existing tax. Given the tax collection agreements adopted in other provinces that have converted retail sales taxes to the HST, Alberta could also enter into a similar agreement.

31 M. Smart, "Departures from Neutrality in Canada's Goods and Services Tax," University of Calgary, School of Public Policy, SPP Research Papers 5, 5 (February 2012). 
Further, Alberta would need to undertake tax reform of some sort given the new revenues it would receive from an HST. It would also lose some flexibility in tax decisions. If Alberta received the same per-capita grant as other provinces, it could receive a one-time transition payment of about $\$ 1.3$ billion from the federal government for adopting an HST harmonized with the federal GST, to make it easier to adopt sales-tax reform.

\section{OUR PRIMARY PROPOSAL}

We propose a major shift in the tax mix for Alberta from personal and corporate income taxes to an Alberta HST on a revenue-neutral basis, which would have the following attributes:

- A more efficient tax structure that promotes growth and higher incomes that would be relatively neutral in its impact on households with different incomes.

- A somewhat less volatile source of revenues compared to the existing tax structure.

- Increased revenues from non-residents who benefit from Alberta services when working or visiting Alberta.

- A reform that does not increase administrative and compliance costs.

A switch from personal and corporate income taxes to the HST, piggy-backed on the existing federal GST in Alberta, would enhance the Alberta tax advantage. We realize any proposal in this study reflects our own view as to what would make a better tax structure in Alberta. We therefore begin with a primary proposal that will be followed by various options, all of which would be subject to debate by Albertans, should they wish to reform the tax system.

In our analysis below, we used the Statistics Canada Social Policy Simulation Data Base and Model. SPSDM is a comprehensive database and model that integrates real income, consumption, and taxation data from Canada's most comprehensive sources, allowing for analysis of the interaction between policy and individual/household economic activity in Canada. The latest version of SPSDM available (based on income, consumption, and taxation data from 2009) has been used to estimate the effects of our proposals for households in different income categories, including the value of consumption taxes, income taxes, and salestax credits. ${ }^{32}$ Our 2013-14 estimate for the value of HST was generated outside of the model based on the most recent data for Alberta GST (2009). We updated values for 2013-14 based on an estimated growth rate for Alberta, which integrates both economic and demographic variables.

The analysis below does not incorporate "behavioural effects" that would likely result in higher revenues being raised after the tax-mix change given economic responses to tax changes. This particularly applies to corporate tax revenues that do not fall as much as predicted by a corporate tax-rate reduction due to increased investment and profit-shifting into Alberta from

32 Although 2009 reflects a recessionary climate, our revenue estimates are based on growth rates that incorporate both economic and demographic variables, and are validated against external sources including estimates in the Alberta budget. As such, revenue estimates are not sensitive to the base year chosen. 
high-taxed jurisdictions..$^{33}$ Further, reductions in personal income taxes tend to have a somewhat bigger impact on increased activity compared to a sales-tax increase that would offset it (as discussed above with respect to the economic cost of raising revenue). However, to incorporate behavioural effects in revenue estimates, a detailed model of the Alberta economy would be needed, that goes beyond this analysis.

\section{An Alberta HST Rate of Eight Per Cent with Personal and Corporate Income Tax Reductions}

Our primary proposal is to introduce a provincial HST rate of eight per cent that would be added to the federal GST rate of five per cent. The Alberta HST rate would therefore be 13 per cent, similar to Ontario, New Brunswick, Nova Scotia (by 2015) and Newfoundland and Labrador, and below that of Prince Edward Island (14 per cent), and Quebec (15 per cent). The Alberta portion of the HST would raise almost $\$ 8$ billion that would be used for personal and corporate income tax reductions, as well as covering the cost of a low-income sales-tax credit.

Most of the revenues would be used to reduce personal income taxes. In our proposal, we increase the personal income tax exemption from the existing $\$ 17,593$ to $\$ 57,250$ (for couples this would result in the first $\$ 114,500$ of personal income not subject to Alberta personal income tax). We also propose a reduction in the personal income tax rate by one point. The combined result of the tax-rate decrease and the personal-exemption increase is that personal income tax revenues are reduced by $\$ 6.3$ billion.

Of the $\$ 8$ billion in sales-tax revenue, about $\$ 700$ million would be used to reduce the general corporate income tax rate from 10 per cent to 8.43 per cent. The corporate tax reduction would partially offset the HST paid on business inputs ( $\$ 955.32$ billion) paid by entities that do not claim an input tax credit for HST on input purchases (e.g., financial firms, and providers of exempt goods such as rental housing).

We do not reduce the small-business tax rate since there is already a large gap in the provincial rates between large/medium- and small-business tax rates, with the small-business rate of three per cent applied to corporate income of up to $\$ 500,000$ with a phasing out of the small-business preference when assets are more than $\$ 10$ million in taxable capital. The differential corporate tax rate imposes a tax on business growth that can be ameliorated by a lower general corporate tax rate. ${ }^{34}$ We also adjust the dividend tax credit downwards to reflect the lower corporate income tax, resulting in an increase of personal income tax revenue equal to $\$ 49$ million.

We introduce an Alberta refundable low-income sales-tax credit similar to the federal GST sales-tax credit, ${ }^{35}$ which would cost $\$ 985$ million. The credit is calculated with a simple formula that takes a base payout value, which is increased by two per cent of each dollar

\footnotetext{
33 See D. Chen and J. Mintz, "2012 Annual Global Tax Competitiveness Ranking: A Canadian Good News Story."

34 D. Chen and J. Mintz, "Small Business Taxation: Revamping Incentives to Encourage Growth," University of Calgary, School of Public Policy, SPP Research Papers 4, 7 (2011).

35 The federal GST low-income tax credit is provided to students and others who might still be living with their families. The credit is calculated for each tax "family" in a household, so a 19-year-old child-technically an adult and family of one, for tax purposes - living with his parents who make over $\$ 500,000$ a year will receive a lowincome sales-tax credit. Thus, some households with relatively high incomes claim the credit, given the presence of more than one tax "family" as defined by Canada Revenue Agency.
} 
earned above a low-income threshold, and reduced by 10 per cent of each dollar earned above a high-income threshold..$^{36}$ The base payout value for our refundable low-income sales-tax credit is $\$ 650$ for each adult, ${ }^{37}$ with an additional $\$ 342.50$ for each child. The low-income threshold over which the credit is increased is $\$ 8,439$, and the high-income threshold over which the credit is decreased is $\$ 41,300$. With the 10-per-cent clawback of the Alberta lowincome tax credit, and the substantial increase in the personal exemption level, the effective marginal personal tax rate for the vast majority of Albertans will not exceed 10 per cent, maintaining the distinctive Alberta flat tax.

Though the cost associated with a provincial HST rate of eight per cent should be roughly 1.6 times that of GST, our Alberta sales-tax credit has base payout values 2.5 times the base payout values of the federal GST tax credit. This is because we have designed the credit to fully preserve after-tax real income and, thus, the purchasing power of lower-income households.

Under the existing personal income tax, 80 per cent of Albertans pay personal income taxes (Figure 2). Under our proposal, about 30 per cent of Alberta households would pay personal income taxes. For those households with between $\$ 60,000$ and $\$ 130,000$ in income, most will be exempt from paying personal income taxes.

\section{FIGURE 2: PERSONAL TAX RATE OF NINE PER CENT WITH A PERSONAL EXEMPTION OF \$57,250 - PERCENTAGE OF HOUSEHOLDS WITH PERSONAL INCOME TAX LIABILITY GREATER THAN \$O}

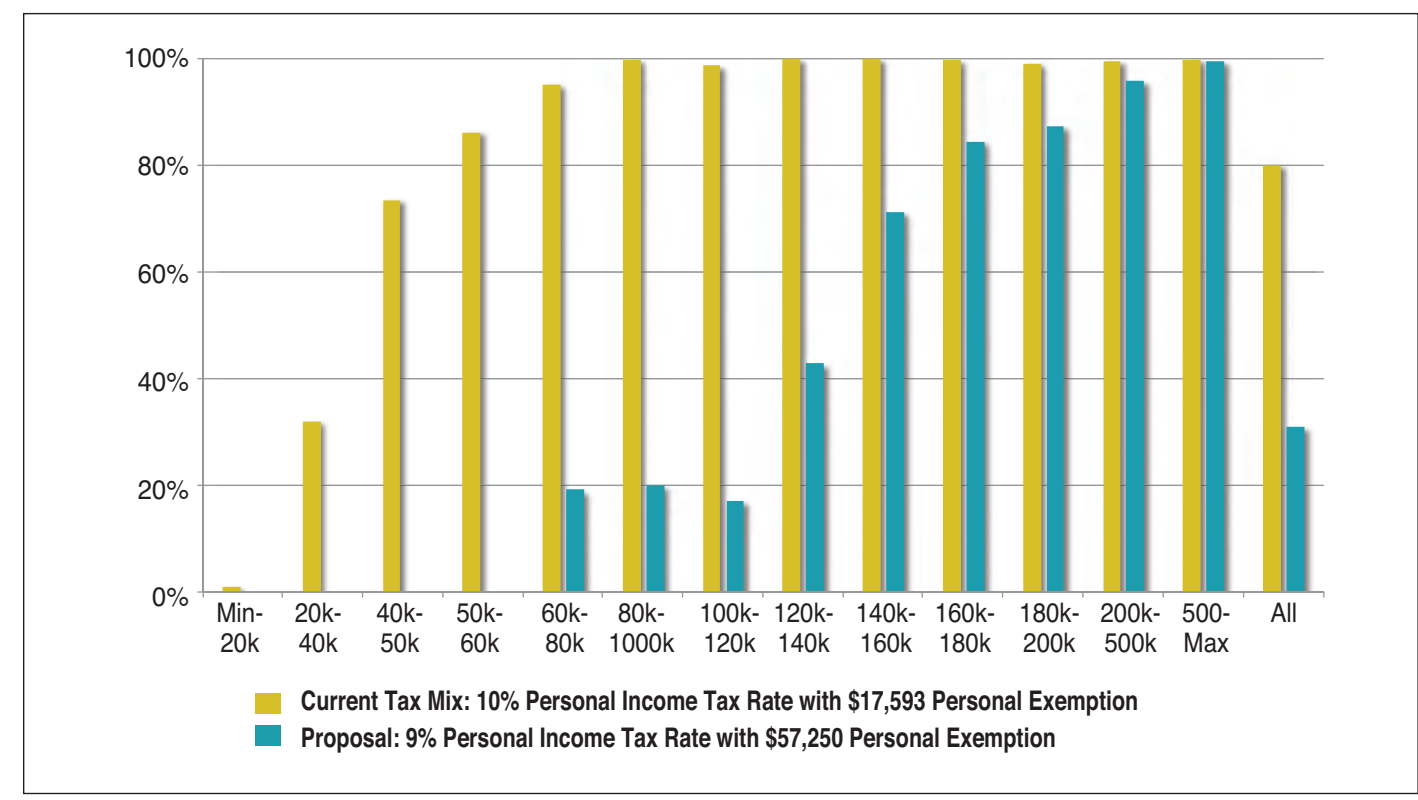

\footnotetext{
36 The low-income tax credit helps maintain the progressivity of the tax system. With the exemption level, Alberta's top effective marginal tax rate is 10 per cent for the vast majority, since we avoid doubling up the personal tax rate and clawback of the low-income tax credit. This differs from the proposal by C. Busby and A. Laurin, "The 8 Percent Solution: A Sensible Tax Compromise for Albertans,” E-Brief, C.D. Howe Institute, Toronto, July 4, 2013.

${ }^{37}$ For a single parent, the base value is doubled. This is also a feature of the federal GST credit.
} 
Under our proposal, the total tax payments for each income class are shown in Figure 3. All households pay less tax directly since some of the tax burden is shifted to non-residents and businesses. Without taking into account any forward shifting of business-level taxes (HST and corporate tax) on households, the overall impact by income class of the proposed shift in the tax mix would result in less tax paid.

\section{FIGURE 3: CURRENT TAX MIX VERSUS PROPOSED TAX MIX}

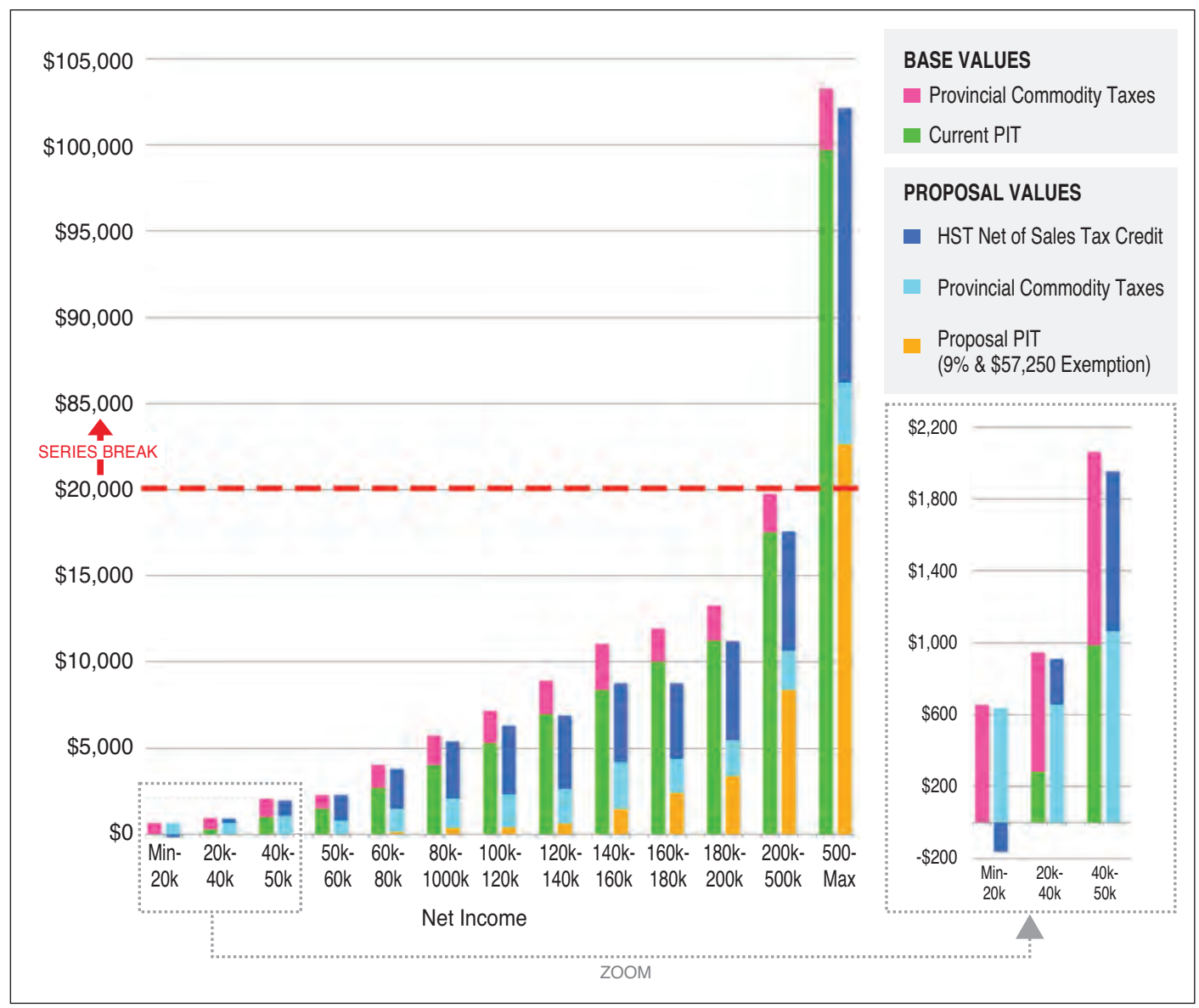

The proposal is described in detail in Tables 9 A and B below. Overall, the proposal would confer a number of benefits on the Alberta economy:

- About two-thirds of Alberta households would no longer pay personal income taxes on their taxable savings.

- With the point reduction in the personal income tax rate, small-business owners will have a lower effective tax rate on income derived from their investments.

- Most Alberta households would pay less tax on their work effort even though sales taxes offset personal income tax reductions.

- The overall progressivity of Alberta's tax system would not be affected significantly.

- The reduction in the general corporate income tax rate will reduce the effective tax rate on new investment from 17.0 per cent to 15.8 per cent, with above-average reductions in the construction and service sectors of the economy. It will offset the impact of any HST paid on capital goods, such as those related to financial-service transactions. 
- Alberta would have the lowest corporate income tax rate in Canada and one that would result in a more competitive business tax system. The reduced corporate income tax rate would also result in a more neutral corporate tax structure. The differential between large and small firms will also be reduced.

- At 23 per cent, large- and medium-sized-business profits will be taxed at a rate lower than the world average. This will encourage many companies to keep profits in Alberta rather than shifting them to other jurisdictions.

TABLE 9A: PERSONAL TAX RATE CUT TO NINE PER CENT AND A PERSONAL EXEMPTION INCREASE WITH A PROVINCIAL HST OF EIGHT PER CENT - GOVERNMENT REVENUE (\$ MILLIONS)

\begin{tabular}{|c|c|c|c|}
\hline \multicolumn{2}{|c|}{$\begin{array}{c}\text { Current Tax Mix } \\
\text { (AB Budget 2013-14 Estimates) }\end{array}$} & \multicolumn{2}{|c|}{$\begin{array}{l}\text { HST with Proposed Rate Cut } \\
\text { and Personal Tax Exemption Increase }\end{array}$} \\
\hline PROVINCIAL HST REVENUE @ 0\% & - & $\$ 7,961$ & PROVINCIAL HST REVENUE @ 8\% \\
\hline HST SALES TAX CREDIT (LIC) & - & $-\$ 985$ & HST SALES TAX CREDIT (LIC) \\
\hline Personal Income Tax Revenue & & & Personal Income Tax Revenue \\
\hline *Personal Income Tax Rate $\mathbf{1 0 \%}$ & & & *Personal Income Tax Rate $\mathbf{9 \%}$ \\
\hline *Personal Exemption $\mathbf{\$ 1 7 , 5 9 3}$ & $\$ 10,001$ & $\$ 3,720$ & *Personal Exemption $\mathbf{\$ 5 7 , 2 5 0}$ \\
\hline (personal \& spouse) & & & (personal \& spouse) \\
\hline Provincial Dividend Tax Credit Rate & & & Provincial Dividend Tax Credit Rate \\
\hline $10 \%$ Eligible \& $3.5 \%$ Ineligible & $\$ 617$ & $\$ 568$ & $\mathbf{8 . 4 3} \%$ Eligible \& $3.5 \%$ Ineligible \\
\hline (reflected in PIT revenue) & & & (reflected in PIT revenue) \\
\hline Corporate Income Tax Revenue & & & Corporate Income Tax Revenue \\
\hline Large Rate: $\mathbf{1 0 \%}$ & $\$ 4,437$ & $\$ 3,740$ & Large Rate: $\mathbf{8 . 4 3 \%}$ \\
\hline Small Rate: 3\% & $\$ 386$ & $\$ 386$ & Small Rate: 3\% \\
\hline TOTAL REVENUE & $\$ 14,824$ & $\$ 14,823$ & TOTAL REVENUE \\
\hline
\end{tabular}

* Personal income tax revenue is net of the dividend tax credit reported in following line. Notes:

The low-income sales-tax credit (LIC) is designed based on the parameters of the federal GST credit with some slight modifications. For this proposal the HST low-income sales-tax credit is calculated with a payout value 2.5 times that of the GST credit, and a clawback rate of 10-per-cent above an income threshold of $\$ 41,300$. 
TABLE 9B: PERSONAL TAX RATE CUT TO NINE PER CENT AND A PERSONAL EXEMPTION INCREASE WITH A PROVINCIAL HST OF EIGHT PER CENT - DISTRIBUTIONAL IMPACT (HOUSEHOLDS, IN DOLLARS) ${ }^{38}$

\begin{tabular}{|c|c|c|c|c|c|c|c|}
\hline & $\begin{array}{c}\text { Change in } \\
\text { Personal } \\
\text { Income Tax } \\
\text { Liability }\end{array}$ & \begin{tabular}{|c|} 
HST Paid \\
on \\
Consumption
\end{tabular} & \begin{tabular}{|c|} 
Low Income \\
Sales Tax \\
Credit (LIC) \\
Received
\end{tabular} & $\begin{array}{c}\text { Net } \\
\text { Increase } \\
\text { in After-Tax } \\
\text { Real Income }\end{array}$ & $\begin{array}{c}\text { Proposal \% } \\
\text { of } \\
\text { Households } \\
\text { with PIT >0 }\end{array}$ & $\begin{array}{c}\text { HST + PIT } \\
\text { net of LIC } \\
\text { as a \% of } \\
\text { Household } \\
\text { Income }\end{array}$ & $\begin{array}{c}\text { Current } \\
\text { Alberta PIT } \\
\text { as a \% of } \\
\text { Household } \\
\text { Income }\end{array}$ \\
\hline \multicolumn{8}{|l|}{$\begin{array}{l}\text { Household Combined } \\
\text { Total Income }\end{array}$} \\
\hline Min - 20k & -1 & 1,032 & 1,194 & 196 & $0.0 \%$ & $-1.2 \%$ & $0.0 \%$ \\
\hline $20 k-40 k$ & -282 & 1,486 & 1,230 & 56 & $0.0 \%$ & $0.9 \%$ & $0.9 \%$ \\
\hline $40 k-50 k$ & -986 & 2,111 & 1,220 & 127 & $0.0 \%$ & $2.0 \%$ & $2.2 \%$ \\
\hline $50 k-60 k$ & $-1,489$ & 2,232 & 744 & 13 & $0.0 \%$ & $2.7 \%$ & $2.7 \%$ \\
\hline $60 k-80 k$ & $-2,559$ & 2,809 & 473 & 235 & $19.2 \%$ & $3.5 \%$ & $3.9 \%$ \\
\hline $80 k-100 k$ & $-3,660$ & 3,625 & 311 & 344 & $20.1 \%$ & $4.1 \%$ & $4.5 \%$ \\
\hline $100 k-120 k$ & $-4,881$ & 4,425 & 408 & 845 & $17.2 \%$ & $4.0 \%$ & $4.8 \%$ \\
\hline $120 k-140 k$ & $-6,334$ & 4,586 & 291 & 1,974 & $42.9 \%$ & $3.8 \%$ & $5.4 \%$ \\
\hline $140 k-160 k$ & $-6,903$ & 4,936 & 341 & 2,226 & $71.2 \%$ & $4.1 \%$ & $5.6 \%$ \\
\hline $160 k-180 k$ & $-7,607$ & 4,788 & 386 & 3,112 & $84.5 \%$ & $4.0 \%$ & $5.9 \%$ \\
\hline $180 k-200 k$ & $-7,863$ & 6,133 & 364 & 2,041 & $87.3 \%$ & $4.8 \%$ & $5.9 \%$ \\
\hline $200 k-500 k$ & $-9,137$ & 7,308 & 367 & 2,146 & $95.8 \%$ & $5.7 \%$ & $6.5 \%$ \\
\hline $500 k+$ & $-17,073$ & 16,161 & 202 & 1,214 & $99.5 \%$ & $7.8 \%$ & $7.9 \%$ \\
\hline All & $-4,011$ & 3,746 & 629 & 884 & $30.9 \%$ & $4.7 \%$ & $5.5 \%$ \\
\hline \multicolumn{8}{|l|}{$\begin{array}{l}\text { Household } \\
\text { Composition }\end{array}$} \\
\hline With Kids, 1 Adult & $-1,391$ & 2,396 & 1,345 & 377 & $3.7 \%$ & $3.1 \%$ & $3.7 \%$ \\
\hline With Kids, 2+ Adult & $-5,382$ & 4,890 & 586 & 1,064 & $36.6 \%$ & $5.0 \%$ & $5.7 \%$ \\
\hline With Elderly, 1 Adult & -901 & 1,565 & 763 & 115 & $8.9 \%$ & $3.4 \%$ & $3.6 \%$ \\
\hline With Elderly, 2+ Adult & $-2,680$ & 3,451 & 775 & 38 & $14.9 \%$ & $3.7 \%$ & $3.7 \%$ \\
\hline Other, 1 Adult & $-2,490$ & 2,263 & 427 & 638 & $36.2 \%$ & $5.2 \%$ & $6.1 \%$ \\
\hline Other, 2+ Adult & $-5,393$ & 4,493 & 607 & 1,473 & $38.6 \%$ & $4.7 \%$ & $5.7 \%$ \\
\hline All & $-4,011$ & 3,746 & 629 & 884 & $30.9 \%$ & $4.7 \%$ & $5.5 \%$ \\
\hline
\end{tabular}

The tax reform would have some other impacts that should be noted. The HST will increase sales taxes paid on many goods and services that will no doubt be criticized.$^{39}$ It will increase the cost of owner-occupied and rental housing (other provinces have reduced HST on newly purchased homes that Alberta will likely wish to do). It could potentially increase tax evasion to the extent that suppliers of final goods and services (such as home renovations) do not charge tax. With many low-income households no longer paying personal income tax and with the modest reduction in the Alberta personal income tax rate, tax incentives for charitable contributions and other similar "tax expenditures" will be less effective (which, depending on one's point of view, might be a good or bad outcome).

38 The low-income sales-tax credit (LIC) is calculated for each tax "family" in a household, as is the case with the GST credit. For instance, a 19-year-old child-technically an adult and family of one for tax purposes - living with his parents who make over $\$ 500,000$ a year will receive a low-income sales-tax credit. This explains the presence of low-income sales-tax credits in high-income households.

39 It is estimated that at least 90 per cent of sales taxes are shifted forward in higher consumer prices. See J. R. Kesselman, "Consumer Impacts of BC's Harmonized Sales Tax: Tax Grab or Pass-Through?," Canadian Public Policy 337, 2 (2011) 139-162, for an analysis of the B.C. sales-tax changes and M. Smart, "Lessons in Harmony: What Experience in Atlantic Canada Shows about the Benefits of the Harmonized Sales Tax," Commentary, No. 253, C.D. Howe Institute (2007), for the Atlantic sales-tax reforms in Newfoundland and Labrador, Nova Scotia and New Brunswick. 


\section{OTHER OPTIONS}

The basic proposal would see Alberta's eight-per-cent-HST revenue being used to reduce a portion of corporate and personal income taxes (Table 9). This, of course, is only one option of many that could be considered as part of a major tax reform. In this section, we look at alternative proposals:

1. Adopting a lower HST rate for Alberta, such as two and five per cent, as compared to eight per cent.

2. Whether Alberta's personal income tax rate should be graduated (progressive) rather than applied at a flat 10-per-cent rate over and above the exemption level.

3. Whether the HST revenues should be revenue-increasing or revenue-decreasing rather than revenue-neutral, which would keep total Alberta taxes the same.

\section{Lower Alberta HST Rates}

We chose eight per cent as the Alberta-HST rate (with a federal-Alberta HST rate of 13 per cent), which is similar to most harmonized provinces. With retail sales taxes in Saskatchewan (five per cent) and British Columbia (seven per cent) that heavily fall on business costs, the eight-per-cent Alberta rate would remain competitive, providing a substantial reduction in personal and corporate taxes. However, the sales-tax rate would be higher than in neighbouring provinces, which encourages cross-border shopping to some degree, especially with Saskatchewan.

Albertans might prefer a lower Alberta-HST rate. An Alberta rate of five per cent would be similar to Saskatchewan's provincial sales-tax rate (the HST rate in Alberta, including the federal portion, would therefore be 10 per cent). A two-per-cent Alberta-HST rate might be preferable since the federal GST was reduced from seven to five per cent (therefore, the combined HST rate would be seven per cent, which was the GST rate before 2006).

In Table 10, we provide some comparisons of tax-mix changes depending on the HST rate chosen for Alberta with the Alberta rate of eight per cent providing a reference in the final column. A combined HST rate in Alberta of seven per cent (two per cent being the provincial portion) would yield $\$ 1.99$ billion that could be used to increase the personal exemption to $\$ 20,150$ if the one-point reduction in the personal income tax rate is maintained. With less revenue obtained from non-residents, the corporate income tax rate is reduced to 9.6 per cent.

The two-per-cent option is attractive since Alberta's HST rate, including the federal portion, would be no different from the previous federal GST rate of seven per cent. However, given the low amount of revenue raised, the economic gains from adopting the HST are relatively minimal, and less dramatic as a shift.

With a combined HST rate of 10 per cent (five per cent for the Alberta portion), Alberta would obtain almost $\$ 5$ billion in revenue. The exemption level would be increased to $\$ 35,025$, with the personal income tax rate reduce by a point as in the other cases. The corporate income tax rate could be reduced from 10 to 8.99 per cent. This proposal would have a stronger impact on the economy compared to the two-per-cent proposal, since taxes would change more substantially. 
TABLE 10: HST AT VARYING RATES WITH PERSONAL INCOME TAX AT NINE PER CENT AND AN INCREASE IN PERSONAL EXEMPTION

\begin{tabular}{|l|c|c|c|c|}
\hline Government Revenue and Expenditures & $\begin{array}{c}\text { Base values } \\
\text { (Current Tax Mix) }\end{array}$ & $\begin{array}{c}\text { Alberta HST } \\
@ \mathbf{2 \%}\end{array}$ & $\begin{array}{c}\text { Alberta HST } \\
@ \mathbf{5 \%}\end{array}$ & $\begin{array}{c}\text { Alberta HST } \\
@ \mathbf{8} \%\end{array}$ \\
\hline Revenue (\$ millions) & & & & \\
HST Revenue Total & - & $\$ 1,990$ & $\$ 4,976$ & $\$ 7,961$ \\
HST Revenue Attributed to AB Residents & - & $\$ 1,791$ & $\$ 4,478$ & $\$ 7,165$ \\
HST Revenue Attributed to Non-residents & - & $\$ 199$ & $\$ 498$ & $\$ 796$ \\
HST Tax Credit Program cost & - & $-\$ 239.70$ & $-\$ 477.80$ & $-\$ 984.80$ \\
HST (net of LIC) Available to Displace PIT & - & $\$ 1,750$ & $\$ 4,498$ & $\$ 6,976$ \\
Personal Income Tax (\$ dollars) & & & & \\
Personal Income Tax Revenue @ Neutrality Given HST & $\$ 10,001$ & $\$ 8,421$ & $\$ 5,951$ & $\$ 3,720$ \\
Deduction Value (personal \& spouse) @ 9\% rate & $\$ 17,593.00$ & $\$ 20,150$ & $\$ 35,025$ & $\$ 57,250$ \\
PIT Rate @ \$17,593 & $9 \%$ & $9 \%$ & $9 \%$ & $9 \%$ \\
Corporate Income Tax (\$ millions) & & & & $9 \%$ \\
Large Rate \% & $10.00 \%$ & $9.61 \%$ & $8.99 \%$ & $8.43 \%$ \\
Large Revenue & $\$ 4,437.00$ & $\$ 4,264$ & $\$ 3,989$ & $\$ 3,740$ \\
Small Rate\% & $3 \%$ & $3 \%$ & $3 \%$ & $3 \%$ \\
Small Revenue & $\$ 386.00$ & $\$ 386.00$ & $\$ 386.00$ & $\$ 386.00$ \\
Total Revenue (net) & $\$ 14,824$ & $\$ 14,821$ & $\$ 14,824$ & $\$ 14,823$ \\
\hline
\end{tabular}

\section{INCREASING PROGRESSIVITY IN ALBERTA'S TAX SYSTEM}

Some have argued for an increase in the personal income tax for upper-income households,${ }^{40}$ which can be viewed as an alternative to introducing the HST as we propose.

We have estimated that a one-point increase in personal income tax rate for individual income above over $\$ 150,000$ would raise $\$ 268$ million. ${ }^{41}$ Increasing Alberta's personal income tax rate from 10 to 16.8 per cent for households with income above $\$ 150,000$ (similar to the newly introduced "temporary" income category in British Columbia) would increase provincial revenues by $\$ 1.24$ billion. This amount is significantly less than introducing a two-per-cent Alberta-HST rate that would generate close to $\$ 2$ billion in revenue.

While a graduated-rate personal tax structure is common across countries to achieve distributional objectives, increased levies on high-income individuals in a province like Alberta would have some negative consequences.

40 See, for example, Alberta Federation of Labour, http://www.betterwayalberta.ca/the-better-way.

41 An increase of one point in the personal income tax for individuals with incomes above $\$ 200,000$ would raise $\$ 226$ million. 
Alberta depends on skilled labour given the importance of its energy industry. Raising taxes on skilled workers (households with more than $\$ 200,000$ in income) would make it less attractive for others to move to Alberta. This could lead to higher wage premiums demanded of skilled workers, somewhat undoing the effect of the tax hike on skilled workers in achieving distributional objectives. ${ }^{42}$

Also, Alberta would be unlikely to raise the expected revenues from a substantial hike in personal income tax rates. A recent estimate suggests that a 10-per-cent increase in the marginal tax rate for incomes above $\$ 150,000$ reduces taxable income by 7.2 per cent. ${ }^{43}$ Thus, a jump in the marginal tax rate from 10 to 16.8 per cent in Alberta on incomes above $\$ 150,000$ would raise only $\$ 510$ million with this estimate.

Given the relatively low amount of revenue raised and the economic costs arising from a lessattractive fiscal framework for skilled workers, a shift to a much more graduated rate structure in Alberta by raising tax rates on high-income individuals from 10 to 16.8 per cent will not provide benefits to the Alberta economy.

However, an option for our specific proposal is to replace the existing Alberta flat tax with a graduated rate structure. For example, the HST revenues could be used to reduce the personal income tax rate below 10 per cent for incomes up to $\$ 150,000$, maintaining the existing rate of 10 per cent for incomes in excess of $\$ 150,000$. An example of this approach is shown in Table 13 where we take a two-rate Alberta personal tax with 6.5 per cent applying to individual income between $\$ 36,625$ and $\$ 150,000$ and 10 per cent on income above $\$ 150,000$. The aftertax real incomes of households change in a pattern similar to our primary proposal, except more taxpayers will be subject to personal income tax, although the marginal tax rate will be reduced by 3.5 per cent for middle-income taxpayers compared to the existing system.

42 This point suggests the sub-national governments have more difficult in redistributing income due to labour mobility within a country. See M. Feldstein and M. Wrobel, "Can States Redistribute Income?" Journal of Public Economics 68, 3 (1998) 369-396. Canadian studies suggest that labour is less mobile. See Kathleen Day and Stanley Winer, "Policy-Induced Internal Migration: An Empirical Investigation of the Canadian Case," International Tax and Public Finance, 13, 5 (2006) 535-64.

43 Canada: Department of Finance "Response of Individuals to Changes in Marginal Tax Rates," Tax Expenditures and Evaluations, Department of Finance, Ottawa, 2010, http://www.fin.gc.ca/taxexp-depfisc/2010/taxexp1003-eng.asp. 
TABLE 11A: PROGRESSIVE TAX RATE AND PERSONAL EXEMPTION INCREASE WITH AN HST - GOVERNMENT REVENUE (\$ MILLIONS)

\begin{tabular}{|c|c|c|c|}
\hline \multicolumn{2}{|c|}{$\begin{array}{c}\text { Current Tax Mix } \\
\text { (AB Budget 2013-14 Estimates) }\end{array}$} & \multicolumn{2}{|c|}{$\begin{array}{l}\text { HST with Progressive Income Tax } \\
\text { and a Personal Tax Exemption Increase }\end{array}$} \\
\hline PROVINCIAL HST REVENUE @ 0\% & - & $\$ 7,961$ & PROVINCIAL HST REVENUE @ 8\% \\
\hline HST SALES TAX CREDIT (LIC) & - & $-\$ 821$ & HST SALES TAX CREDIT (LIC) \\
\hline Personal Income Tax Revenue & & & Personal Income Tax Revenue \\
\hline *Personal Income Tax Rate $\mathbf{1 0 \%}$ & & & *Personal Income Tax Rate \\
\hline $\begin{array}{l}\text { *Personal Exemption } \mathbf{\$ 1 7 , 5 9 3} \\
\text { (personal \& spouse) }\end{array}$ & $\$ 10,001$ & $\$ 3,575$ & $\begin{array}{l}\text { 6.5\% on income under 150k \& } \mathbf{1 0 \%} \text { over } \\
\text { *Personal Exemption } \mathbf{\$ 3 6 , 6 2 5} \\
\text { (personal \& spouse) }\end{array}$ \\
\hline Provincial Dividend Tax Credit Rate & & & Provincial Dividend Tax Credit Rate \\
\hline $\begin{array}{l}10 \% \text { Eligible \& } 3.5 \% \text { Ineligible } \\
\text { (reflected in PIT revenue) }\end{array}$ & $\$ 617$ & $\$ 567$ & $\begin{array}{l}\mathbf{8 . 3 9 \%} \text { Eligible \& } 3.5 \% \text { Ineligible } \\
\text { (reflected in PIT revenue) }\end{array}$ \\
\hline Corporate Income Tax Revenue & & & Corporate Income Tax Revenue \\
\hline Large Rate: $\mathbf{1 0 \%}$ & $\$ 4,437$ & $\$ 3,723$ & Large Rate: $\mathbf{8 . 3 9 \%}$ \\
\hline Small Rate: $3 \%$ & $\$ 386$ & $\$ 386$ & Small Rate: 3\% \\
\hline TOTAL REVENUE & $\$ 14,824$ & $\$ 14,824$ & TOTAL REVENUE \\
\hline
\end{tabular}

* Personal income tax revenue is net of the dividend tax credit reported in following line. Notes:

The low-income sales-tax credit (LIC) is designed based on the parameters of the federal GST credit with some slight modifications. For this proposal the HST low-income sales-tax credit is calculated with a payout value 2.5 times that of the GST credit, and a clawback rate of 10-per-cent above an income threshold of $\$ 33,884$. 
TABLE 11B: PROGRESSIVE TAX RATE AND PERSONAL EXEMPTION INCREASE WITH AN HST - DISTRIBUTIONAL IMPACT (HOUSEHOLDS, IN DOLLARS)

\begin{tabular}{|c|c|c|c|c|c|c|c|}
\hline & $\begin{array}{c}\text { Change in } \\
\text { Personal } \\
\text { Income Tax } \\
\text { Liability }\end{array}$ & \begin{tabular}{|c|} 
HST Paid \\
on \\
Consumption
\end{tabular} & \begin{tabular}{|c|} 
Low Income \\
Sales Tax \\
Credit (LIC) \\
Received
\end{tabular} & \begin{tabular}{|c|} 
Net \\
Increase \\
in After-Tax \\
Real Income
\end{tabular} & \begin{tabular}{|c|}
$\begin{array}{c}\text { Proposal } \% \\
\text { of } \\
\text { Households } \\
\text { with PIT > } 0\end{array}$ \\
\end{tabular} & $\begin{array}{c}\text { HST + PIT } \\
\text { net of LIC } \\
\text { as a \% of } \\
\text { Household } \\
\text { Income }\end{array}$ & $\begin{array}{c}\text { Current } \\
\text { Alberta PIT } \\
\text { as a \% of } \\
\text { Household } \\
\text { Income }\end{array}$ \\
\hline \multicolumn{8}{|l|}{$\begin{array}{l}\text { Household Combined } \\
\text { Total Income }\end{array}$} \\
\hline Min - 20k & -1 & 1,032 & 1,194 & 196 & $0.0 \%$ & $-1.2 \%$ & $0.0 \%$ \\
\hline $20 k-40 k$ & -281 & 1,499 & 1,184 & 0 & $0.0 \%$ & $1.1 \%$ & $0.9 \%$ \\
\hline $40 k-50 k$ & -995 & 2,058 & 722 & -288 & $0.0 \%$ & $2.9 \%$ & $2.2 \%$ \\
\hline $50 k-60 k$ & $-1,496$ & 2,221 & 435 & -264 & $0.0 \%$ & $3.3 \%$ & $2.7 \%$ \\
\hline $60 k-80 k$ & $-2,605$ & 2,805 & 353 & 169 & $17.9 \%$ & $3.6 \%$ & $3.9 \%$ \\
\hline $80 k-100 k$ & $-3,779$ & 3,628 & 253 & 400 & $19.0 \%$ & $4.0 \%$ & $4.5 \%$ \\
\hline $100 k-120 k$ & $-4,970$ & 4,438 & 316 & 832 & $27.4 \%$ & $4.1 \%$ & $4.8 \%$ \\
\hline $120 \mathrm{k}-140 \mathrm{k}$ & $-6,310$ & 4,564 & 237 & 1,921 & $54.1 \%$ & $3.9 \%$ & $5.4 \%$ \\
\hline $140 k-160 k$ & $-7,024$ & 4,930 & 297 & 2,307 & $79.9 \%$ & $4.0 \%$ & $5.6 \%$ \\
\hline $160 k-180 k$ & $-8,091$ & 4,800 & 329 & 3,512 & $85.9 \%$ & $3.8 \%$ & $5.9 \%$ \\
\hline $180 k-200 k$ & $-8,741$ & 6,161 & 279 & 2,775 & $87.3 \%$ & $4.4 \%$ & $5.9 \%$ \\
\hline $200 k-500 k$ & $-10,309$ & 7,345 & 313 & 3,185 & $94.9 \%$ & $5.2 \%$ & $6.5 \%$ \\
\hline $500 k+$ & $-9,508$ & 16,043 & 188 & $-6,127$ & $99.6 \%$ & $8.4 \%$ & $7.9 \%$ \\
\hline All & $-4,104$ & 3,747 & 524 & 870 & $33.0 \%$ & $4.7 \%$ & $5.5 \%$ \\
\hline \multicolumn{8}{|l|}{$\begin{array}{l}\text { Household } \\
\text { Composition }\end{array}$} \\
\hline With Kids, 1 Adult & $-1,360$ & 2,390 & 1,199 & 214 & $3.7 \%$ & $3.4 \%$ & $3.7 \%$ \\
\hline With Kids, 2+ Adult & $-5,393$ & 4,889 & 490 & 984 & $41.1 \%$ & $5.1 \%$ & $5.7 \%$ \\
\hline With Elderly, 1 Adult & -925 & 1,565 & 707 & 83 & $8.9 \%$ & $3.4 \%$ & $3.6 \%$ \\
\hline With Elderly, 2+ Adult & $-2,716$ & 3,447 & 629 & -64 & $15.0 \%$ & $3.8 \%$ & $3.7 \%$ \\
\hline Other, 1 Adult & $-2,742$ & 2,268 & 333 & 783 & $34.4 \%$ & $5.0 \%$ & $6.1 \%$ \\
\hline Other, 2+ Adult & $-5,519$ & 4,496 & 495 & 1,481 & $42.5 \%$ & $4.7 \%$ & $5.7 \%$ \\
\hline All & $-4,104$ & 3,747 & 524 & 870 & $33.0 \%$ & $4.7 \%$ & $5.5 \%$ \\
\hline
\end{tabular}

\section{NON-REVENUE NEUTRAL TAX REFORM}

In the proposal above, a tax-mix shift raises no additional revenues for the government since the new HST revenues are used to reduce personal and corporate income taxes. While not incorporated in our estimates, we do expect some new revenues from increased economic activity and profit shifting by multinationals, but we have not tried to estimate new revenues from these sources. These additional revenues could help fund public services and infrastructure.

Nonetheless, it would also be useful to consider in more detail whether the tax reform should be revenue-increasing or -decreasing, rather than revenue-neutral as assumed in our proposals so far.

Currently, Alberta has a significant fiscal deficit with program expenditures outstripping revenues. With the recent southern-Alberta floods, additional expenditures are required for relief and mitigation. It becomes a political decision as to whether the province should use new sales-tax revenue to help fund public services, including municipal infrastructure. 
FIGURE 4: ALBERTA PROGRAM SPENDING PER PERSON

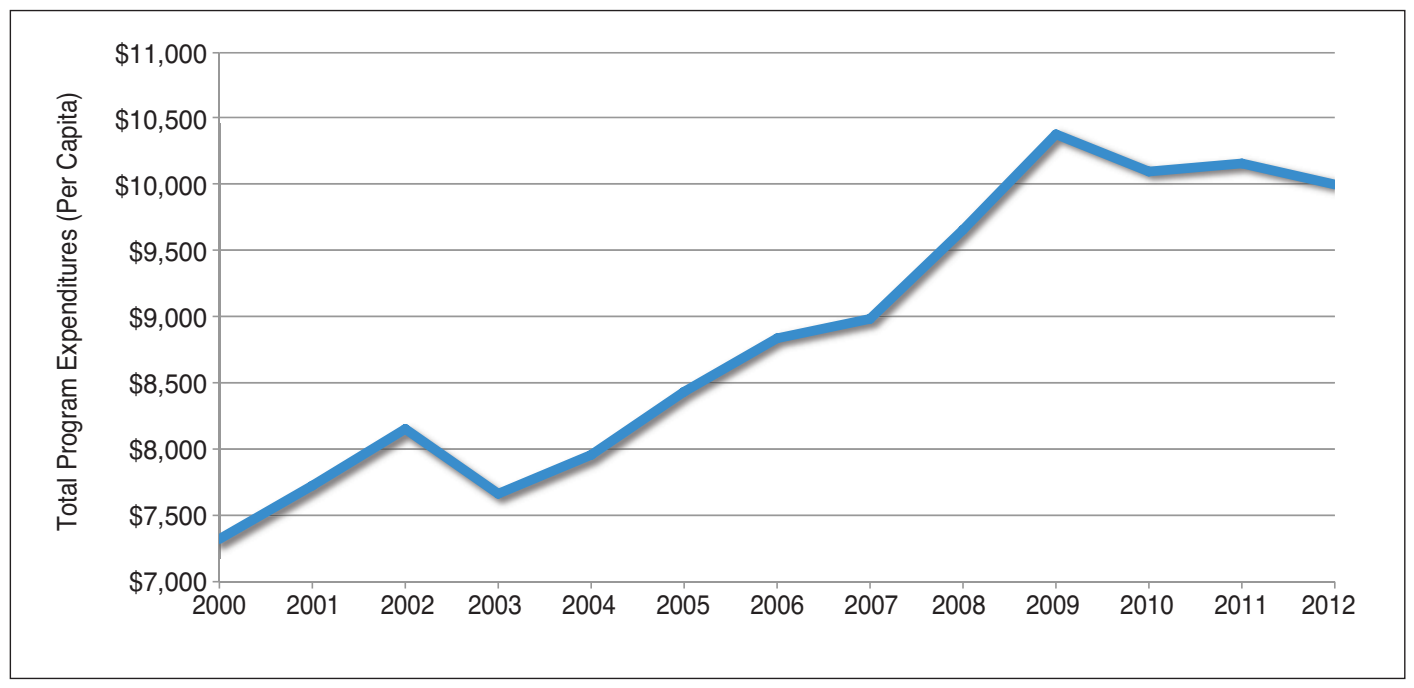

Notes: Values are presented in 2012 dollars.

Program expenditure values: Fiscal Reference Tables.

Population values: Cansim Table 051-0001.

Some Albertans argue that the province does not need to raise more revenue but instead, needs to show greater spending constraint as program spending has risen faster than population and prices in the past decade. Certainly, per-capita program spending in 2012 (Figure 2) had increased sharply between 2001 and 2009, leveling off in the past three years.

Others have argued that the province has used too much of its royalty revenues from nonrenewable resource extraction to fund provincial spending levels, rather than saving such funds for the future. Therefore, new taxes are needed to fund public services and infrastructure, while non-renewable resource revenues are saved for the future.

It is therefore an open question as to whether tax reform should increase revenues or not. Although we are focused in this study on the tax structure, the discussion around the introduction of an Alberta sales tax will no doubt focus on revenue requirements as well. We do note the following:

First, tax reforms are more difficult for the public to accept if they raise revenues. Many new sales taxes around the world have been introduced to keep revenues constant, including the federal GST, which replaced the federal manufacturers' sales tax, and recent sales reforms in Ontario, Quebec and the Atlantic provinces that replaced retail sales taxes with multi-stage VATs and income tax reductions. Politicians need to make a strong case as to the reasons that governments need extra revenue besides creating more growth through a better tax structure. When governments do need revenue, voters would like to ensure they benefit from larger public budgets in the future.

Second, it is possible for tax changes to be revenue-neutral for Albertan households, but with revenues collected from non-residents and businesses used to fund provincial expenditures or to be transferred to municipalities as a grant. Further, any new revenues from increased economic activity could be used to fund public services. 
A different approach is to introduce the HST by reducing overall taxes paid by Albertans. This approach was used for the introduction of the flat tax in Alberta, which was accompanied by a reduction in revenue of $\$ 1.5$ billion in 2001. It helps make a tax reform more popular if taxes are also reduced for a large part of the population. For example, the introduction of a revenue-neutral flat tax would have raised taxes on middle-income groups to cover the cost of tax reductions for high- and low-income Albertans who benefit most from rate reductions and exemption increases respectively.

Given Alberta's current deficit, the virtual elimination of the revenue-stabilization fund (the Sustainability Fund) and a sharp reduction in net financial assets by $\$ 4$ billion expected in the 2013-14 fiscal year, it is highly unlikely that a tax reform with a loss in revenues will be achievable without further straining Alberta's fiscal health.

\section{CONCLUSIONS}

Alberta currently has the opportunity to enhance its tax advantage by introducing a harmonized sales tax, while maintaining revenue neutrality through major reductions in corporate and personal income taxes.

By reducing reliance on personal and corporate income taxes, and introducing consumption taxes, the province can shift its tax mix toward less volatile, more efficient sources of revenue. The proposals presented in this paper illustrate a few of the options that can achieve these ends, while protecting low-income Albertans from the regressive effects of consumption taxes.

A revenue-neutral HST would also present the opportunity to lower corporate income taxes. This would reduce disparities in effective tax rates across business activities, and lessen distortions in the corporate tax system promoting growth and productivity in Alberta's economy. This would create incentives for businesses to invest in Alberta, bringing new jobs and opportunities to the province.

The prospect of capturing the HST associated with non-resident tourism is another benefit for all Albertans. HST associated with non-resident consumption currently represents a forgone revenue stream for the province somewhere in the range of $\$ 800$ million. This is a significant source of untapped revenue available to the Alberta government to help fund public services.

The introduction of a harmonized sales tax is also attractive given its low administrative cost for government and compliance cost for business. Governments and businesses are already equipped for the GST and, so, face minimal costs in incorporating an HST. As an HST would apply to the same tax base in place for the GST, the introduction of an HST in Alberta would largely amount to a change of tax rate for those who administer the GST.

In closing, we present this paper with the hope that our proposal for a revenue-neutral HST will persuade Albertans to consider current opportunities to enhance the provincial tax mix detached from the politically charged sentiments that have often dominated discussion of a revenue-generating consumption tax in the province. 


\title{
ABOUT THE SCHOOL OF PUBLIC POLICY
}

The School of Public Policy will become the flagship school of its kind in Canada by providing a practical, global and focused perspective on public policy analysis and practice in areas of energy and environmental policy, international policy and economic and social policy that is unique in Canada.

The mission of The School of Public Policy is to strengthen Canada's public service, institutions and economic performance for the betterment of our families, communities and country. We do this by:

- Building capacity in Government through the formal training of public servants in degree and nondegree programs, giving the people charged with making public policy work for Canada the hands-on expertise to represent our vital interests both here and abroad;

- Improving Public Policy Discourse outside Government through executive and strategic assessment programs, building a stronger understanding of what makes public policy work for those outside of the public sector and helps everyday Canadians make informed decisions on the politics that will shape their futures;

- Providing a Global Perspective on Public Policy Research through international collaborations, education, and community outreach programs, bringing global best practices to bear on Canadian public policy, resulting in decisions that benefit all people for the long term, not a few people for the short term.

\author{
The School of Public Policy \\ University of Calgary, Downtown Campus \\ 906 8th Avenue S.W., 5th Floor \\ Calgary, Alberta T2P $1 \mathrm{H} 9$ \\ Phone: 4032107100
}

\section{DISTRIBUTION}

Our publications are available online at www.policyschool.ca.

\section{DISCLAIMER}

The opinions expressed in these publications are the authors' alone and therefore do not necessarily reflect the opinions of the supporters, staff, or boards of The School of Public Policy.

\section{COPYRIGHT}

Copyright (C) 2013 by The School of Public Policy.

All rights reserved. No part of this publication may be reproduced in any manner whatsoever without written permission except in the case of brief passages quoted in critical articles and reviews.

\section{DATE OF ISSUE}

September 2013

\section{MEDIA INQUIRIES AND INFORMATION}

For media inquiries, please contact Morten Paulsen at 403-453-0062.

Our web site, www.policyschool.ca, contains more information about The School's events, publications, and staff.

\section{DEVELOPMENT}

For information about contributing to The School of Public Policy, please contact Courtney Murphy by telephone at 403-210-7201 or by e-mail at cdmurphy@ucalgary.ca.

\section{ISSN}




\section{RECENT PUBLICATIONS BY THE SCHOOL OF PUBLIC POLICY}

\section{ACCOUNTABILITY BY DESIGN: MOVING PRIMARY CARE REFORM AHEAD IN ALBERTA}

http:/ / policyschool.ucalgary.ca/ ?q=content/ accountability-design-moving-primary-care-reform-ahead-alberta Dr. Shannon M. Spenceley, Cheryl Andres, Janet Lapins, Dr. Robert Wedel, Dr. Tobias Gelber, L.M. Halma | September 2013

WIRELESS COMPETITION IN CANADA: AN ASSESSMENT

http:/ / policyschool.ucalgary.ca/?q=content/ wireless-competition-canada-assessment Jeffrey Church and Andrew Wilkins | September 2013

THE CANADIAN MANUFACTURING SECTOR, 2002-2008: WHY IS IT CALLED DUTCH DISEASE? http:/ / policyschool.ucalgary.ca/ ?q=content/ canadian-manufacturing-sector-2002-2008-why-it-called-dutchdisease

Stephen Gordon | September 2013

REDISTRIBUTION OF INCOME: POLICY DIRECTIONS

http:/ / policyschool.ucalgary.ca/?q=content/ redistribution-income-policy-directions James Davies | August 2013

INCOME INEQUALITY AND INCOME TAXATION IN CANADA: TRENDS IN THE CENSUS 1980-2005 http:// policyschool.ucalgary.ca/?q=content/income-inequality-and-income-taxation-canada-trends-census1980-2005

Kevin Milligan | August 2013

INCOME INEQUALITY, REDISTRIBUTION AND ECONOMIC GROWTH http:/ / policyschool.ucalgary.ca/?q=content/income-inequality-redistribution-and-economic-growth Bev Dahlby and Ergete Ferede | August 2013

DIPLOMACY, GLOBALIZATION AND HETEROPOLARITY: THE CHALLENGE OF ADAPTATION http:/ / policyschool.ucalgary.ca/ ?q=content/ diplomacy-globalization-and-heteropolarity-challenge-adaptation Daryl Copeland | August 2013

UNHEALTHY PRESSURE: HOW PHYSICIAN PAY DEMANDS PUT THE SQUEEZE ON PROVINCIAL HEALTH-CARE BUDGETS

http:/ / policyschool.ucalgary.ca/?q=content/ unhealthy-pressure-how-physician-pay-demands-put-squeezeprovincial-health-care-budgets

Hugh M. Grant and Jeremiah Hurley | July 2013

TRENDS, PEAKS, AND TROUGHS: NATIONAL AND REGIONAL EMPLOYMENT CYCLES IN CANADA http:/ / policyschool.ucalgary.ca/?q=content/trends-peaks-and-troughs-national-and-regional-employmentcycles-canada

Ronald Kneebone and Margarita Gres | July 2013

THE FISCAL, SOCIAL AND ECONOMIC DIVIDENDS OF FEELING BETTER AND LIVING LONGER

http:/ / policyschool.ucalgary.ca/?q=content/ fiscal-social-and-economic-dividends-feeling-better-and-living-longer J.C. Herbert Emery, Ken Fyie, Ludovic Brunel and Daniel J. Dutton | June 2013 